I NTER NATIONAL MONETARY FUND

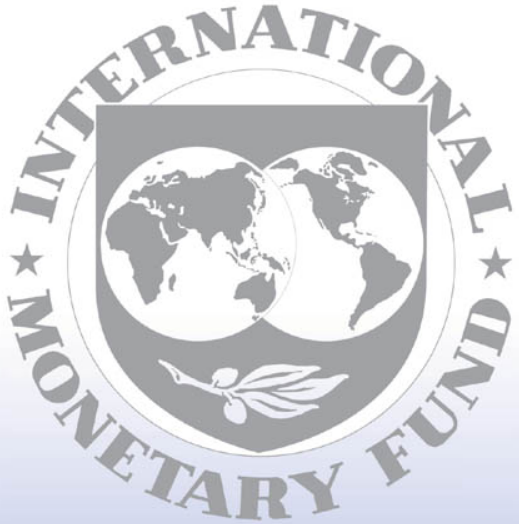

Staff

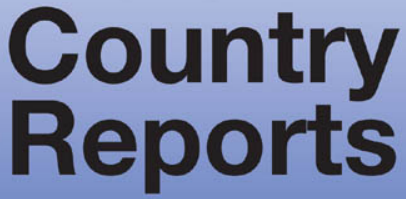


March 2000

IMF Staff Country Report No. 00/46

\section{Monetary and Exchange Rate Policies of the Euro Area}

This report was prepared by a staff team of the International Monetary Fund following discussions with the euro-area authorities on monetary and exchange rate policies. The report was then considered by the IMF's Executive Board in the context of the Article IV discussions with euro-area countries, as required under Article IV of the IMF Articles of Agreement. The views expressed in the staff report itself are those of the staff team and do not necessarily reflect the views of the Executive Board of the IMF or of the euro-area authorities. The views of the Executive Board as expressed in the context of the discussion of the Article IV consultation report and as summarized in a Public Information Notice (PIN) are also included. In addition, a statement by Joao Santos, on behalf of the euro-area authorities, is appended. Further background documentation prepared by IMF staff for the consultation may be published separately at a later date. The policy of publication of Article IV staff reports allows for the deletion of market sensitive information.

This staff report in the context of Article IV consultations is published-both in hard copy and on the IMF's website (http:/www.imf.org) — as part of a pilot project. To assist the IMF in evaluating the pilot project for release of Article IV staff reports, reader comments on the staff report are invited prior to October 5, 2000, and may be sent by e-mail to Pilotproject@imf.org.

Copies of this report are available to the public from

International Monetary Fund Publication Services

700 19th Street, N.W. Washington, D.C. 20431

Telephone: (202) 623-7430 Telefax: (202) 623-7201

Telex (RCA): 248331 IMF UR

E-mail: publications@imf.org

Internet: http://www.imf. org

Price: $\$ 15.00$ a copy

\section{International Monetary Fund}

Washington, D.C. 


\section{INTERNATIONAL MONETARY FUND}

\section{Monetary and Exchange Rate Policies of the Euro Area}

(In the Context of the 1999 Article IV Discussions with Euro-Area Countries)

Prepared by the European I Department

Approved by Michael Deppler and Leslie Lipschitz

February 23, 2000

Contents

I. Introduction 3

II. Policy Discussions ............

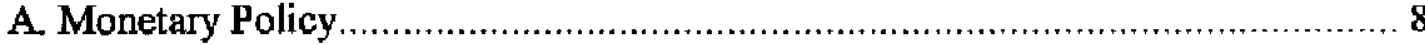

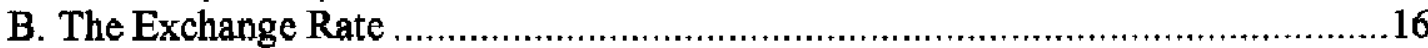

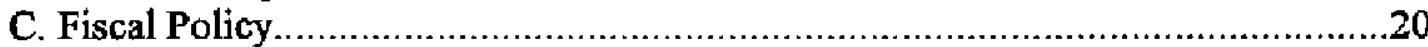

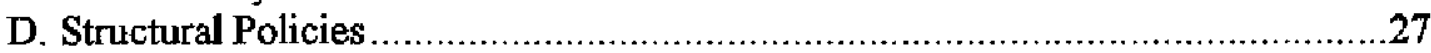

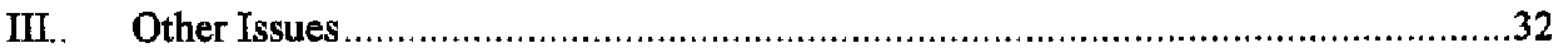

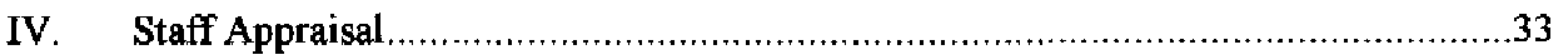

Boxes

1. Economic Developments and Prospects ....................................................... 4

2. The Information Content of Money and the ECB's Reference Value

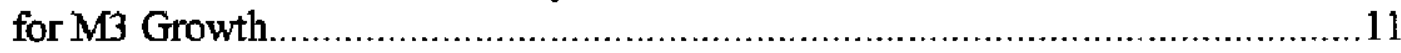

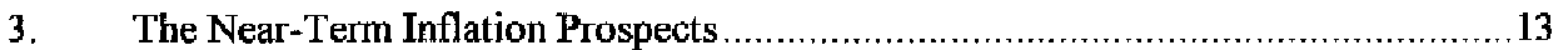

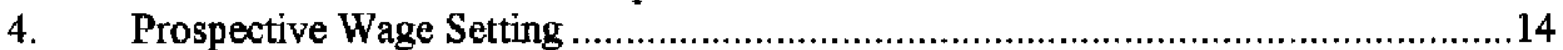

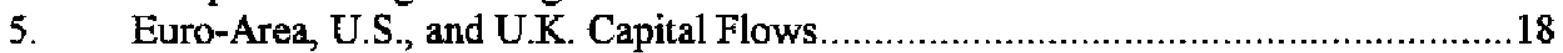

6. The Updated Stability Programs .........................................................25

7. The EU's Own Diagnosis and Recommendations on Labor Market Policies ..........29

Tables

1. Staff Medium-Term Fiscal Projections...........................................................21

2. Overall Balances and Revenue Ratios Under the Old and New Stability Programs

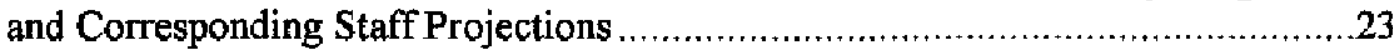

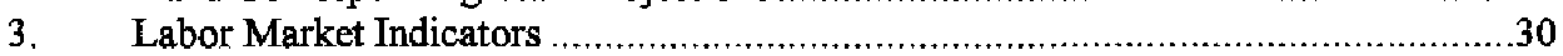




\section{Figures}

1. Recent Developments in the Euro Area. 6

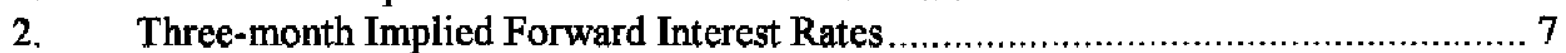

3. $\quad$ Monetary Conditions in the Euro Area........................................................... 9

4. Rolling Forecasts for 2000 GDP Growth and the Euro-U.S. Dollar

Exchange Rate...................................................................................17

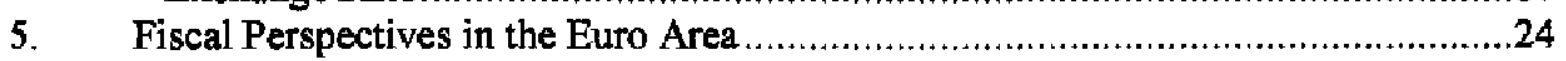

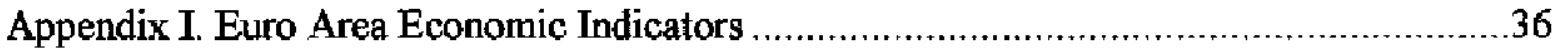




\section{INTRODUCTION}

1. This paper marks the beginning of a second cycle of Fund surveillance of the monetary and exchange rate policies of the euro area, which were last discussed by Directors on March 26, 1999 (BUFF/99/44) and further described by the staff in a follow-up report issued for the information of the Executive Board on August 23, 1999 (SM/99/212).

2. In preparation for the paper, a mission ${ }^{1}$ visited the European Central Bank (ECB), where it held talks with President Duisenberg, Messrs. Issing and Padoa-Schioppa (both members of the ECB Executive Board), and senior staff. It also visited the Commission of the European Communities (Commission), where discussions were held with Commissioner Solbes Mira, Mt. Ravasio (Director General for Economic and Financial Affairs), and some of their collaborators. The staff made also a presentation to the Economic and Financial Committee (EFC) $)^{2}$ and had follow-up talks with its Chairman, Mr. Lemierre. For the first time, the staff presented the concluding statement of the mission to the Euro-11 Finance Ministers, at their January meeting.

3. The area-wide econonic situation has improved markedly over the past year. At the time of the March 1999 Board discussion, the economy was weakening. The staff projected a rebound in the second half of 1999 and in 2000 , but with serious, incipient downside risks. In this context, Directors noted the limited scope for operation of the automatic stabilizers in several countries burdened by relatively high deficits or debt, and argued that the case for an interest rate cut was becoming stronger. Many Directors also thought that for most euro-area countries the medium-term fiscal programs lacked ambition, and expressed concern about the disappointing progress overall in tackling structural rigidities and, in particular, the root causes of persistent unemployment.

4. By the time of the interim staff visit in mid-1999, there were already growing signs that the awaited pickup in activity was underway against the backdrop of a supportive monetary stance and a recovering global environment. This trend has continued in recent months, and the prospects for 2000 can now be described as quite favorabie. On current WEO

\footnotetext{
${ }^{1}$ The mission took place on December 6-14, 1999, and the mission team comprised Messrs. Artus (Head), Zanello, Ross, and Annunziata (all EU1), Mr. Caramazza (RES), and Mr. Rosenblatt (PAR). Mr. Grisse, the ECB Observer at the Executive Board of the IMF, participated in the discussions at the ECB.
}

${ }^{2}$ The EFC is a consultative body that prepares the work of the Council of Finance Ministers. Its members are senior officials of national Finance Ministries and central banks, the Commission, and the ECB. 


\section{Box 1. Euro Area: Economic Developments and Prospects}

As Stage 3 of EMU started, euro-area growth-which had slowed down in the wake of the emerging markets crises-aimost stalled under a growing external drag that weakened indistrial activity. The negative external contribution was however progressively offset during the first half of the year by a stronger intemal demand benefiting from sustained employment creation, falling inflation, improved confidence and financial conditions of households and enterprises, ample availability of credit, and bullish stock markets. The area-wide poticy mix was also suppontive, with only modest fiscal consolidation envisaged in the 1999 budgets and a timely monetary easing in early Spring in response to mounting deflation risks.

By mid-1999, the recovery in the global economy and a very competitive position of the euro catalyzed a further acceleration in aggregate real GDP growth to well above potential, although the pattern of growth remained geographically unbalanced, with Italy and Germany lagging behind other large economies, and the smaller peripheral countries (Ireland, Finland, Portugal, and the Netherlands) leading the cycle. Labor market performance was also uneven, with unemployment rates ranging from $3-5$ percent in some small sountries to 9-11 percent in the larger ones (Spain being an outlier with 15 percent). For the area as whole, the overall unemployment rate continued to

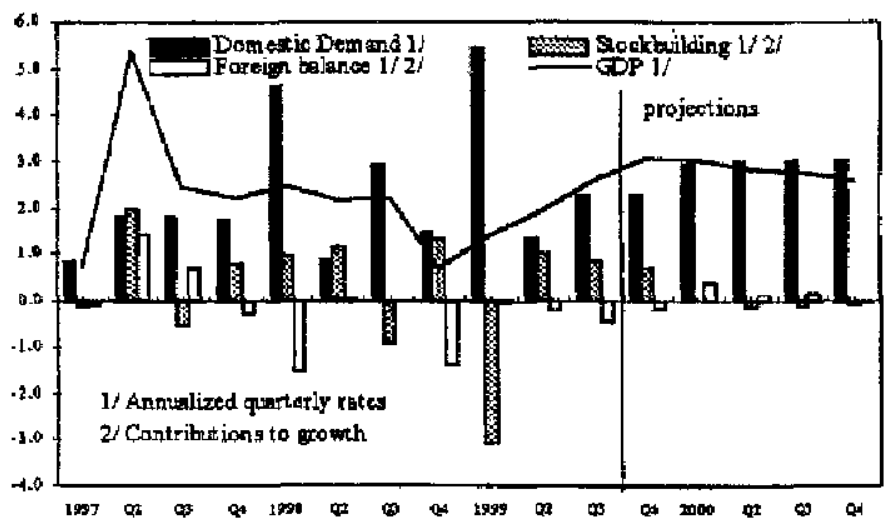
decline, reaching 9.6 percent in the fourth quarter.

Throughout the year, headline inflation, which had bottomed out in winter 1998-99 at about 1 percent, remained subdued, albeit on an upward trend, and reached 1.7 percent (year-on-year) last December. However, core inflation, as measured by the aggregate Harmonized Index of Consumer Prices (HICP) net of its energy and food components, continued to decline through October, when it attained the all-time low of 0.9 percent, before edging up to 1.1 percent in December. The difference between the highest (Ireland) and the lowest (France) national rate of HICP 12-month increase was on the order of $21 / 2$ percent as of December.

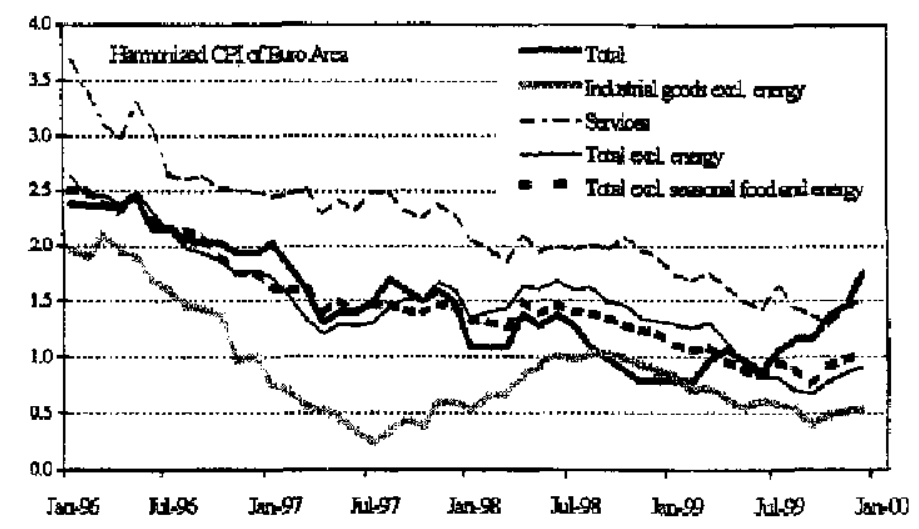

On current WEO projections, aggregate real GDP growth is poised to reach 3.1 percent in 2000 and 3.2 percent in 2001 (broadly in line with the latest Commission's and Consensus Econonics forecasts). The inflation outlook is expected to remain benign, with headline HICP inflation tapering off by end-2000 to 1.6 percent and remaining in 2001 well within the ECB medium-term target range, against a backdrop of a still sizeable output gap for the area as a whole, at -1.2 percent in 2000 and -0.4 percent in 2001 . Regional divergences in growth and inflation rates, reflecting mainly the catching-up process in many euro countries, are expected to continue, although narrowing somewhat. The optimism for 2000 relies on the expectation that intemal dernand will benefit from cynamic job creation and falling unemployment that will support confidence and disposable income, and will foster a further reduction in presautionary savings. Overall, household consumption is expected to provide the strongest contribution to growth although, with favorable business sentiment and still low cost of credit, investment activity will pickup. World demand for euro zone exports is expected to revert to a more moderate rhythrn than in late 1999. However, in spite of growing imports, the external contribution will still turn positive on average for the year.

Risks to the near-term outlook for inflation appear balanced, with upward potential in the prospects for economic activity. On the dowtuside, real growth projections are mainly subject to uncertainties stenining from the global environment: most importantly, the timing and intensity of a possible siowdown in the United States. 
forecasts, euro-area real GDP growth would exceed 3 percent in 2000 in a setting of price stability and a sizable current account surplus (see Box 1 ).

5. This change in the economic outlook was mirrored by a shift in the focus of the policy discussions during the December mission. Taking center stage in the talks were the sustainability of the economic expansion, the scope for and timing of a move to a more neutral monetary stance, the policy implications of the weakening euro, and the appropriate mediumterm fiscal and structural reform strategies in the brighter conjunctural setting. There were also discussions of the evolving process of policy coordination and internal surveillance in the euro and EU areas. Less emphasis was given to the short-term orientation of fiscal policy, agricultural and single-market issues, and recent financial sector developments and banking sector issues (the latter of which will be addressed by the upcoming International CapitaI Markets report).

\section{POLICY Discussions}

6. The representatives of the ECB and the Commission, and the representatives of the national authorities at the EFC were optimistic about the strength of the euro-area recovery and the near-term outlook (Figure 1). The mission shared this view, but noted that the experience of the last few decades cast a shadow on the longer-run sustainability of the expansion. Entrenched economic rigidities had kindled inflationary pressures in the early phase of past economic upswings, requiring corrective monetary tightening and leading to a steady tatcheting up of euro-area unemployment.

7. The challenge was to avoid repeating this past experience. While, according to the mission, economic growth could be sustained at a rate somewhat above 3 percent for a year or two without undue risk to price stability, the more prolonged expansion needed to bring euro-area unemployment down to acceptable levels would require further structural changes. Reforms on many fronts - privatization and deregulation, in particular-had already secured some favorable structural changes, and the overall macroeconomic setting had improved with the successful fiscal consolidation and disinflation in the run-up to EMU. However, labor market flexibility remained limited, and the public sector continued to weigh heavily on economic activity. Moreover, addressing some structural impediments to a prolonged expansion was viewed as politically taboo in many euro-area countries. This was probably why market participants seemed to entertain an even more skeptical view of the sustainability of the recovery than the mission-as evidenced by the weak euro and expectations of a steep hike in short-term interest rates in 2000-01 (Figure 2)

8. There was a clear recognition among the representatives of the EU institutions and national authorities that positioning the euro-area economy on a high-growth path was the key policy challenge, and that this would require a sustained pace of fiscal, and labor and product market reforms. In particular, members of the Euro-11 ministerial group saw the coming 
Figure 1. Recent Developments in the Euro Area
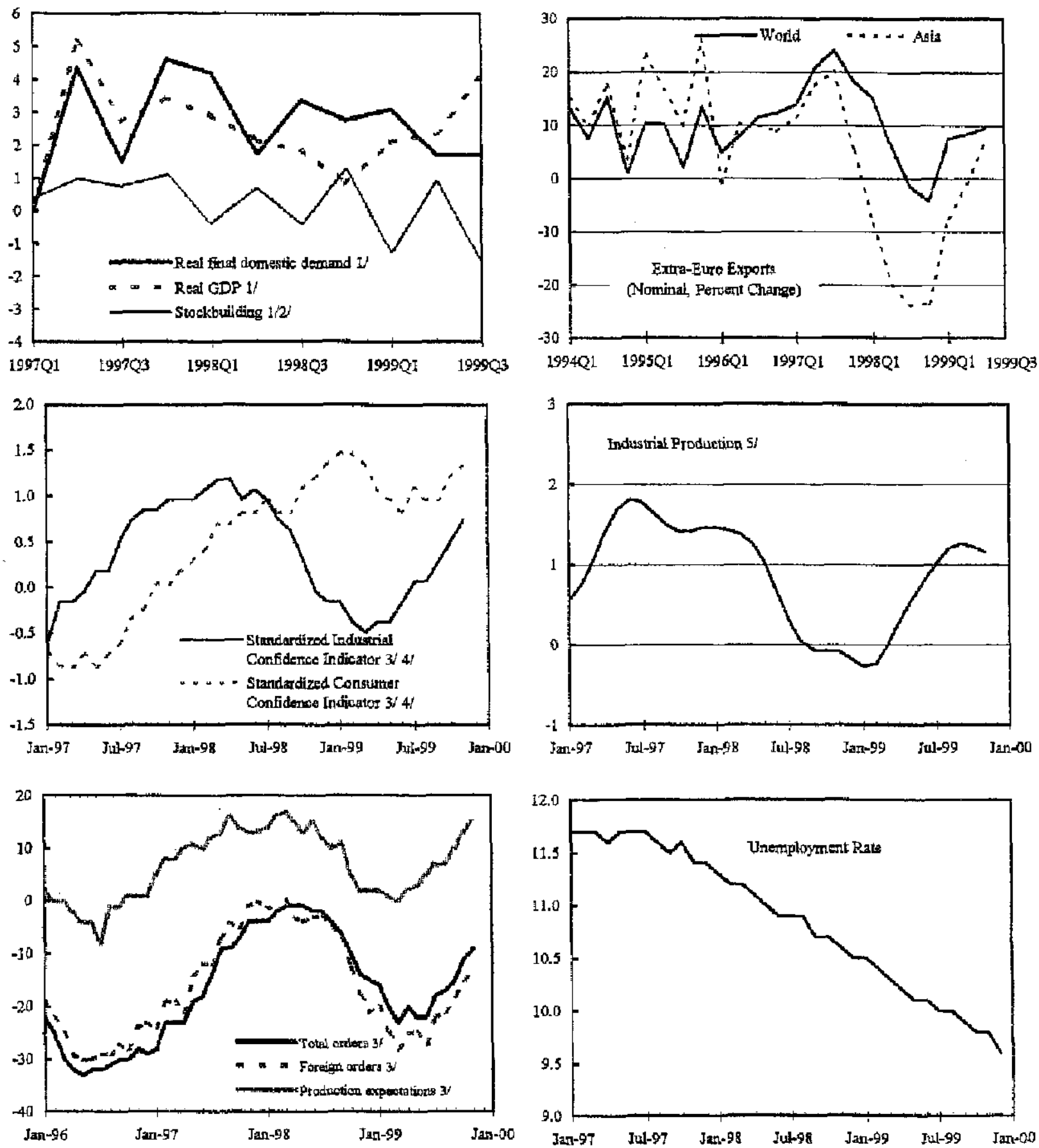

Sources: RMF, Worid Economic Outlook; WEFA datebase; and Europear Commission.

1/ Quarterly growth, atunalized.

2/ Contribution to grouth

3/ Survey, balance of responses.

4/ Centered, standardized series; rneans and standard deviations refer to period June 1986 to present.

s/ Percent change of the average of the last 3 raonths over the previous 3 months. 
Fìgure 2. Euro Area: Three-month Implied Forward Interest Rates.

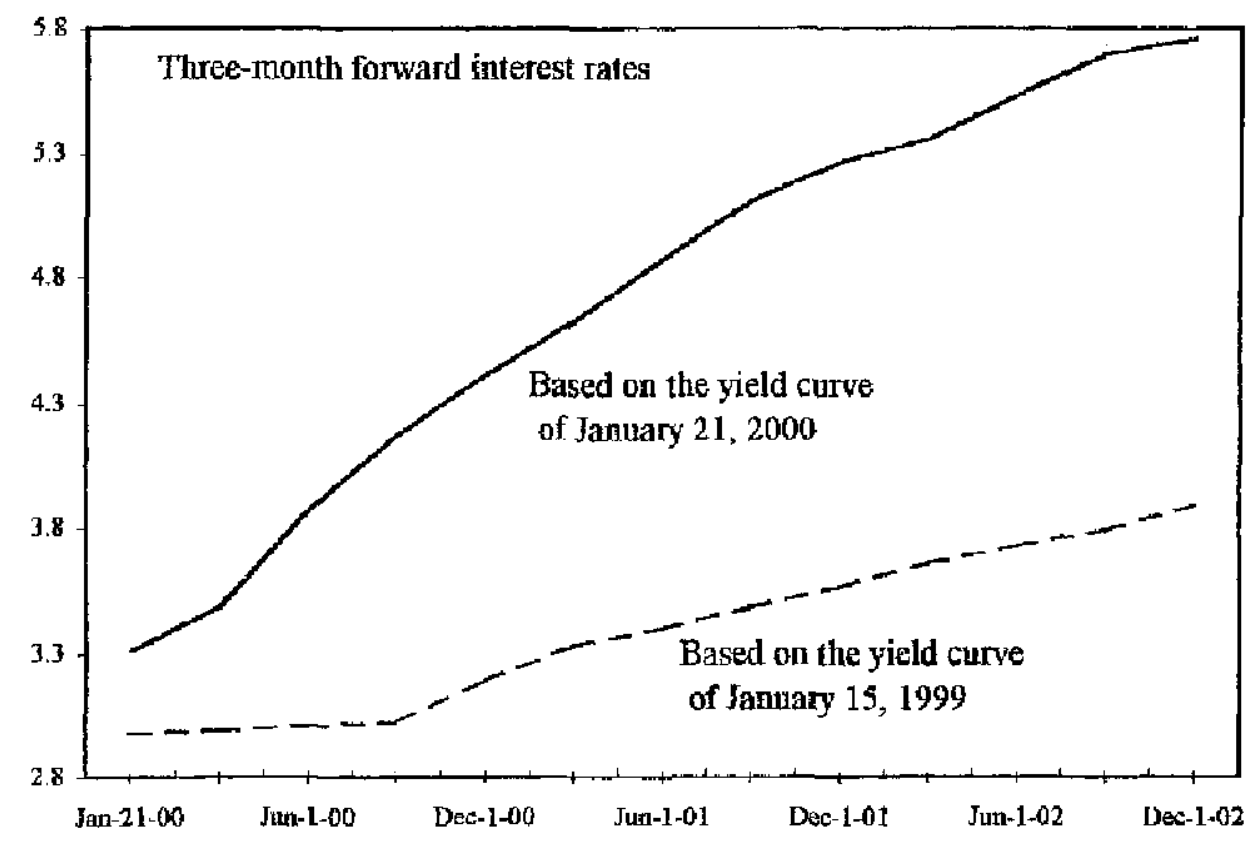

Source: Bloonberg. 
Lisbon meeting of the European Council as providing an opportunity to put forward a more vigorous program of structural reforms. Different emphasis was placed, however, on the specific measures to be taken.

\section{A. Monetary Policy}

9. In discussing recent developments on the policy front, ECB representatives explained that the decision in November to reverse the April interest rate reduction represented a return to a less accommodative monetary stance, as the risk of deflation had disappeared. In their opinion, a gradual shift in the balance of risks to price stability toward the upside had been implied by rapid monetary growth, a better established recovery, upbeat consumer and business sentiment, an acceleration in wage demands in some countries, and the bottomingout of producer prices. ${ }^{3}$ In any case, monetary and financial conditions (Figure 3) remained quite supportive of activity:

- short-term interest rates were in all likelihood still below what could be viewed as their cyclically neutral real levels, and were lower in real terms than at the previous cyclical trough in the early $1990 \mathrm{~s}$;

- in an historical perspective, the real effective exchange rate for the euro area hovered at about 13 percent below its average over the last decade;

- broad money had accelerated through December to a three-month average growth rate of about 6 percent (well above the ECB's $4 \frac{1}{2}$ percent reference value for annual M3 growth), with $\mathrm{M} 1$ growing much faster, as maturity substitution favored short-term deposits. Moreover, credit to the private sector had expanded at an annual rate in excess of 10 percent;

- the slope of the yield curve had steepened significantly, with average nominal yields on long-term government bonds having increased since mid- 1999 by some 135 basis points, or 60 basis points more than short rates; ${ }^{4}$ and

${ }^{3}$ ECB Press Conference of November 4, 1999. See http $/ / \mathrm{www} . \mathrm{ecb}$.int $/ \mathrm{key} / \mathrm{st} 991104 \mathrm{htm}$.

${ }^{4} \mathrm{ECB}$ officials noted that the hike in long-term interest rates mirrored, with a lag, comparable increases in U.S. long rates. The better prospects for global economic growth and some pickup in inflationary expectations on both sides of the Atiantic appeared to be the main contributing factors. 
Figure 3. Monetary Conditions in the Euro Area
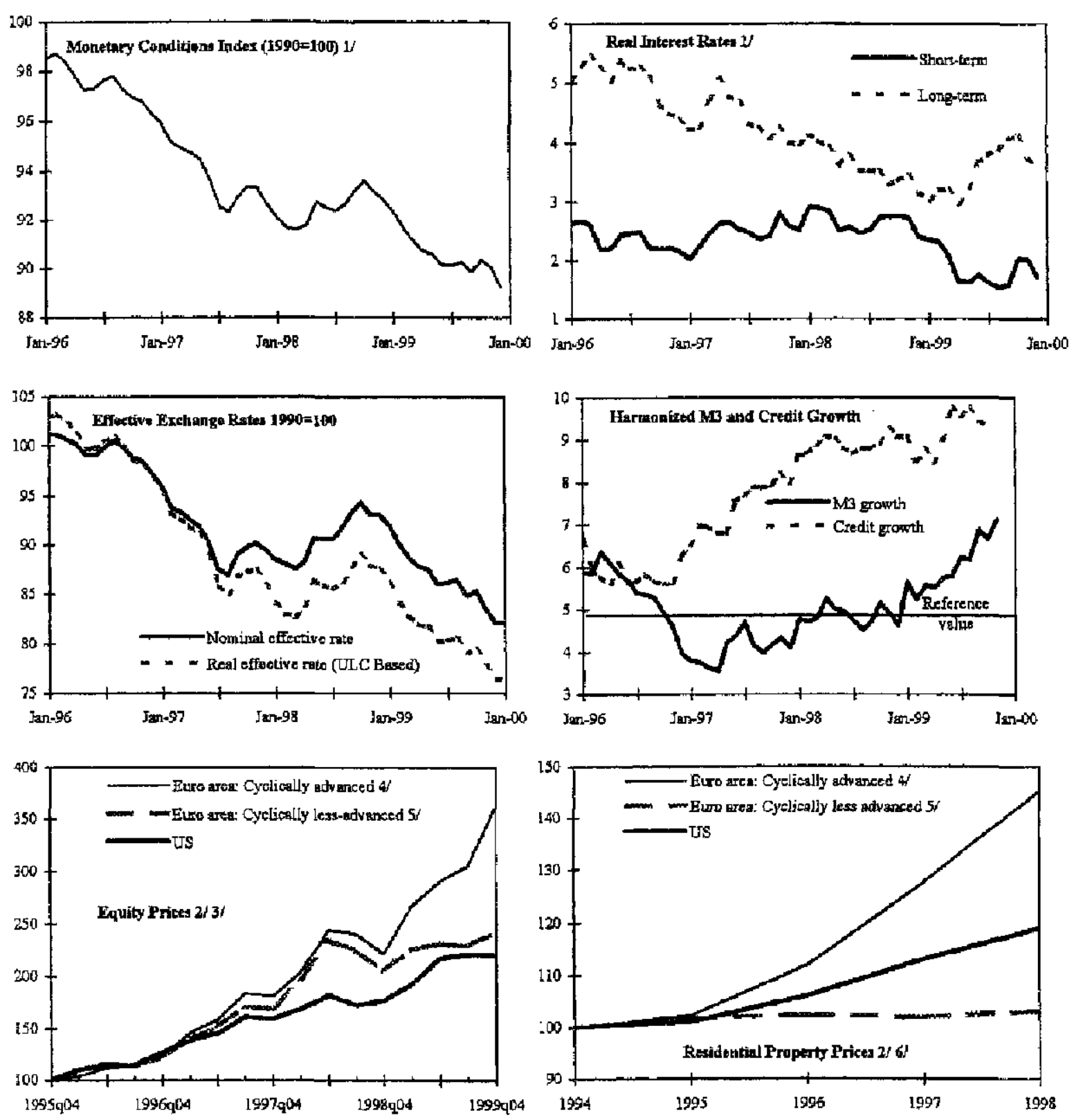

Sources: IMF; European Central Bank; Bloomberg; National Association of Realtors; Ring Daucher Makler; Ministere de l'Equipement des Transport et đu Logement; Nomisima; national data.

1/ Real interest rates are defined as nominal interest rates minus core price inflation in the preceeding 12 month (using the harmonized index of consumer prices from Janusry 1996).

2/ Excluding Luxembourg and Portugal (unweighted averages).

3/ Quarterly averages, fourth quarter 1995=100.

4/ Finland, Ireland and the Netheriands.

5/ Austria, Belgium, France, Gameny, Italy and Spain.

6. Year-end data, $1995=100$. 
- euro-area equity prices as well as real estate prices in some peripheral countries continued on an upward trend, likely reinforcing through wealth effects the supportive monetary conditions. ${ }^{5}$

10. The mission broadly concurred that the deflation risks had indeed disappeared in the second half of the year, and that this had warranted a retum to a more neutral, but still accommodative, monetary stance. Nonetheless, medium-term inflation risks seemed largely absent. Inflation was picking up in some of the smaller countries, but this was not the case in the bulk of the euro-area economy and, therefore, should not much influence monetary policy. In addition, the uncertain information content of monetary data (Box 2) raised questions about their relevance for policymaking at a time when asset-holders were still adapting to the new monetary regime.

11. In reply, the officials agreed that monetary policy should be focused on the euro-area economy as a whole. However, they stressed: (i) that the ECB's monetary framework called for-and found strength in-a careful overall evaluation of a broad set of indicators under the two "pillars" of the monetary framework; (ii) that the special factors affecting monetary developments in the first months of EMU's Stage 3 did not contradict the existence of a stable (and empirically well-documented) linkage between money and prices in the longer run; (iii) that, while most central projections-including their own-foresaw an inflation rate of less than 2 percent over 2000-01, the shift in the balance of risks to medium-term price stability in the fall of 1999 had justified an upward adjustment in interest rates to avoid a situation where the emergence of serious inflation risks in the future would require a larger interest rate correction; and (iv) that markets had reacted positively to the interest rate increase, ${ }^{7}$ suggesting a broad understanding of its rationale.

12. Looking ahead, ECB representatives and the mission shared the view that no immediate further tightening was required, barring unforeseen developments in wages or prices, given the eatly phase of the recovery and the fact that a rise in headline inflation in the first half of 2000 had already been factored into the policy decisions. With a maturing

\footnotetext{
${ }^{5}$ The euro-area stock market index (Stoxx 50) rose by about 40 percent in 1999. In gauging the economic impact of such an increase, it should be noted that stock ownership in Europe is some five times less widespread than in the United States. On the other hand, private consumption seems to respond more to increases in real property prices in the euro-area countries than in the United States. (See WEO 2000, Chapter 3, forthcoming).

${ }^{6}$ Broadly speaking, the two pillars of the monetary strategy are a reference value for monetary growth and consideration of a wide range of other indicators of future price developments.

${ }^{7}$ Long and short interest rates fell in the aftermath of the ECB decision to raise its policy rates last November.
} 


\section{Box 2. The Information Content of Money and the ECB's Reference Value for M3 Growth}

Careful consideration of the evolution in euro-area monetary aggregates constitutes the "first pillar" of the Eurosystem's monetary policy strategy. Accondingly, in deciding to increase the main refinancing rate last November and in early February, the ECB pointed inter alia at the ongoing growth of broad money above its reference value as a possible harbinger of future inflation.

This element of the strategy has been criticized by some ECB-watchers as deficient because it gives a prominent role in analysis and communication to money-growth indicators judged to be largely irrelevant. The criticism echoes the long-running debate surounding the usefulness of monetary aggregates as a predictor of euro-area inflation, given a possibly unstable money demand. Indeed, econometric evidence shows that in normal circumstances the information content of broad money growth for inflation forecasts in the short and medium term seems quite low (see, for example, Gerlach, S. and L. Svensson, Money and Inflation in the Euro Area: $A$ Case for Monetary Indicators?, mimeo, July 1999). On the other hand some researchers have found a stable long-nin relationship between real income, interest rates, and the inflation rate for the euro area, which supports the prominent role given to money aggegates by the ECB (see, for example, Coener, G. and J-I. Vega, "The Demand for MS in the Euro Area." ECB Working Paper, September 1999).

In the present context, the main issue is whether the information content of money is likely to be significant under the very special eircumstances of the introduction of a new currency, when money demand is likeiy to be unpredictable and possibly unstable, owing to evolving portfolio preferences as well as to structural changes in financial markets and banking.

The figure at right lends some tentative support to the view that velocity under Stage 3 of EMU may have departed from its trend-which enters in the determination of the ECB's reference value ${ }^{1}$-and appears less closely linked to movements in interest rates, possibly impiying a structural shift in the demand for money.

The empirical evidence is not clear-cut, however. The ECB staff has extensively tested the assumption that velocity is stationary around a declining linear trend and has concluded that, while shocks to velocity may persist for quite some time. they will eventually die out However, the statistical tests for this conclusion have low

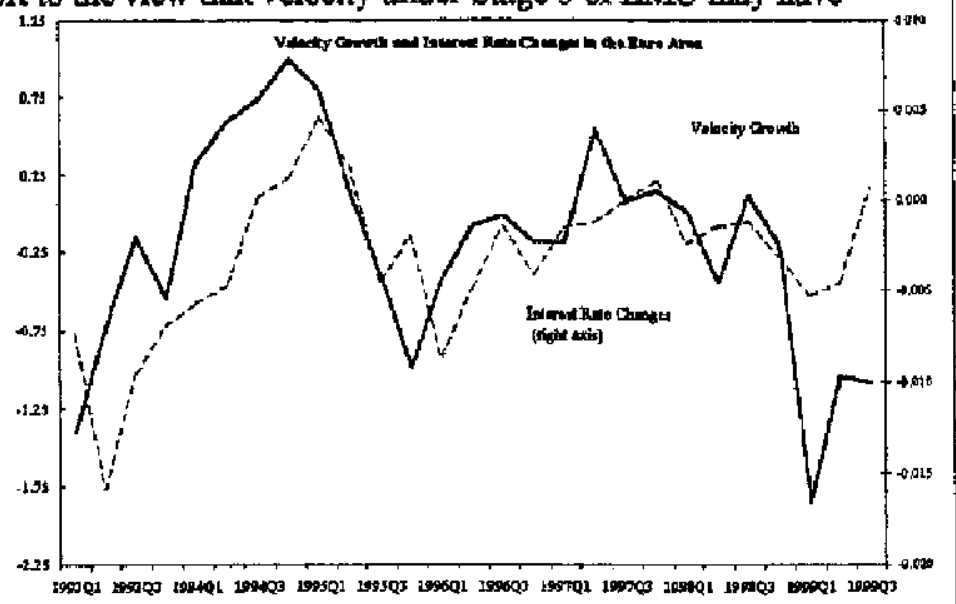
power, and at this stage it remains unclear what might be the implication of M3 growth above its reference vałue. $^{2}$

1 The ECB's 41/2 percent reference value for broad money growth is the midpoint of a range of possible growth rates for broad money consistent with a quantity-theoretic representation of long-tun aggregate demand and estimates for target inflation, output growth, and a velocity trend.

${ }^{2}$ Anmual percentage changes in M3 averaged 4.8 percent in the last quanter of $1998,5.3$ percent in both the tirst and second quarters of 1999 , and 5.9 percent in the third quarter, and above 6 percent in the fourth quarter. Bas: effects have somewhat complicated the interpretation of the evolution of monetary aggregates. 
economic expansion, of course, a gradual shift to a less accommodative stance would be expected. The mission stressed, however, that future policy moves should be geared only to clear threats to medium-term price stability (taking account of the lags in the effects of a monetary policy change) and should not allow a bias for preemptive tightening to unduly stunt area-wide growth.

13. Subsequently to the discussion, on February 3, 2000, the ECB raised its principal refinancing rate by 25 basis points, pointing to heightened inflation risks that could be seen in: (i) the continued expansion of both M3 and credit, ${ }^{8}$ and (ii) larger and more protracted increases in oil and commodity prices than foreseen earlier, as well as import price pressures from the continuing stide of the euro, in the context of stronger prospects of a lasting upswing in the euro-area economy. ${ }^{2}$ While acknowledging the points made by the ECB, the staff believes that, even with only a fairly gradual return to a neutral monetary stance by 2001 , medium-term price stability is not threatened: inter alia on the basis of projected wage moderation and productivity growth, the staff expects inflation to quickly move back within the ECB's 2 percent inflation band after a spike in the first half of 2000 , with core inflation hovering in the $1-1 \frac{1}{2}$ percent range over the next two years (Boxes 3 and 4).

14. As regards the ECB's communication strategy, the mission tecognized the impressive effort made in the pursuit of a high degree of transparency. Yet, it stressed the need for still clearer explanations of how interest rate policy reflected threats to medium-ternt price stability, and it wondered whether the recent practice of "talking to the markets" had been successful. In this connection, ECB officials noted that markets had not been surprised by the November interest rate increase.

15. More broadly, ECB representatives underscored that as a supranational central bank, the ECB faced unprecedented challenges in its ability to reach effectively a plurality of audiences accustomed to different communication protocois and semantic nuances. While a release of economic forecasts (including on inflation) might help to further explain the Governing Council's assessment of the outlook for price stability, ECB officials stressed forcefully that this move would not represent a switch to an inflation targeting framework,

${ }^{8}$ The three-month average of the anmual growth rate of $\mathrm{M} 3$ - the indicator followed by the $\mathrm{ECB}$-rose to 6.1 percent in December 1999. However, the annualized six-month growth rate of M3 (seasonally adjusted) fell from 7.9 percent in June to 5 percent in September. It has since remained within the range of 5.0-5.5 percent, indicating that $\mathrm{M} 3$ expansion was more subcued during the second half of 1999.

${ }^{9}$ ECB Press Conference of February 3, 2000. See http: $/ /$ www ecb jnt/key/00/sp000203.htm. 


\section{Box 3. Ruro Area: The Near-Term Inflation Prospects}

On current staff's projections, headline inflation is expected to peak in the second quarter of 2000 at just above 2 percent, driven by the increase in oil prices during 1999, and then to decline quickly well below the ECB's target ceiling of 2 percent inflation.

By contrast, core inflation (defined as the annuat increase in the Harmonized Index of Consumer Prices (HICP) net of its more volatile energy and food components) is forecast to edge up only slightly above its end-1999 rate, and peak in the first quarter of 2001 at about 1.3 percent. This hump-shaped path for core inflation is suggested by three alternative vector autoregressive (VAR) specifications of the inflation process. ${ }^{1}$ The figure below shows the average core-inflation forecast from the three models. It also presents the projected headline rate, obtained as a weighted average (using Eurostat's HICP weights) of core inflation and inflation in the HICP energy component on current WEO assumptions for oil prices, ${ }^{2}$

Forecasts based on VAR models of (the rate of change of) prices (excluding seasonal food items and energy), money (M3), wages, and output growth as well as the nominal effective exchange rate, show that annual core inflation would peak at about $11 / 4$ percent in the first quarter of 2001 and decline thereafter to below 1.1 percent by end-2001. In these specifications, a unit increase in labor costs results in a $\% / 4$ of 1 percent increase in core inflation over 2 years.

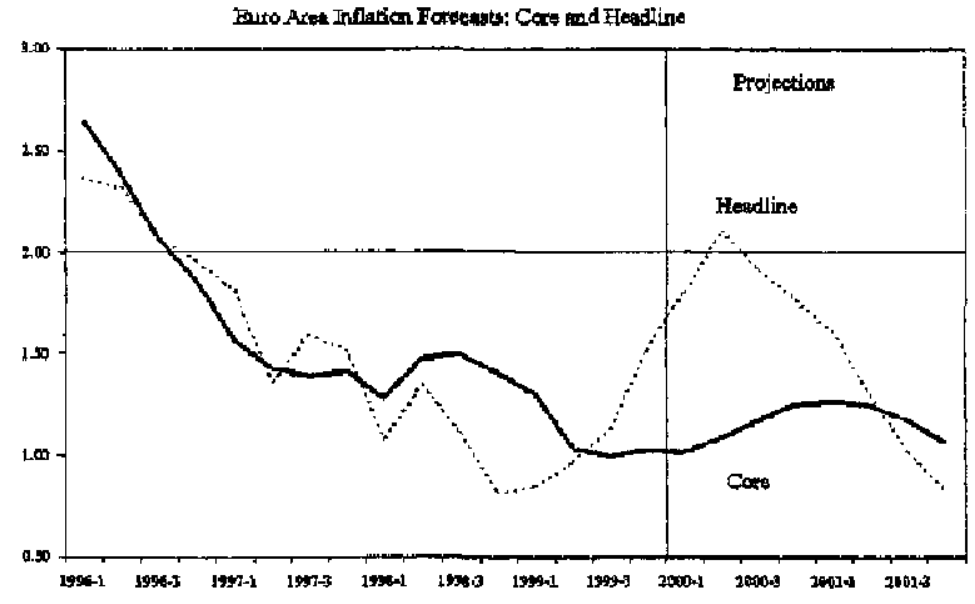

On an annual-average basis, headline inflation in the euro area would be 1.9 percent in 2000 , and hover at about 1.2 percent in 2001 . These projections are in line with the latest WEO and January Consensus Economics forecasts of euro-area inflation for 2000 (at about 1.6 percent), but somewhat lower for 2001. Core inflation, however, is expected to remain broadly unchanged over $2000-01$.

Thus, the forecasting exercises point to a mild deterioration of the heatline inflation outlook for 2000 , but not to a threat to redium-term price stability. The possibility of a wage-price spiral and a pick up in imported inflation creates some upside risk to the projection. However, there are also downside risks related to potential deflationary pressures in four key sectors —electricity, gas, and transport and communications services-where further market liberalization and deregulation could significantly enhance the play of competitive

\begin{tabular}{lccccc}
\multicolumn{5}{c}{ Liflation Forecasts } \\
\hline & \multicolumn{2}{c}{2000} & \multicolumn{2}{c}{2001} \\
\cline { 2 - 3 } \cline { 5 - 6 } WEO & Consensus & WEO & Consenstis \\
\hline Euro-11 & 1.6 & 1.6 & 1.5 & 1.6 \\
France & 1.5 & 1.1 & 1.1 & 1.1 \\
Germany & 1.1 & 1.4 & 1.3 & 1.6 \\
Italy & 2.0 & 1.9 & 1.5 & 1.7 \\
Spain & 2.3 & 2.3 & 2.2 & 2.2 \\
\hline
\end{tabular}
forces.

${ }^{1}$ Frojections of inflation based upon VAR models should be treated with caution, given possible complications arising from internalizing a policy reaction function

${ }^{2}$ Under current WEO technical assumptions, oil prices would peak in the first quarter of 2000 at about $€ 26.3$ per barrel (period average) and decline throughour $2000-2001$, reaching $€ 22.0$ by end -2000 and $€ 18.1$ by end-2001. 


\section{Box 4. Euro Area: Prospective Wage-Setting}

With lingering uncertainties about the interpretation of monetary data (Box 2), the upcoming rounds of wage negotiations throughout the euro area will be particularly significant in signaling risks to medium-term price stability-and, hence, in shaping monetary policy for the near term.

The timing of the wage rounds in some key countries raises concern, as it coincides with the projected peak of the inflation path (Box 3) and may work against the unions" strategy of wage-moderation and employmentfriendly settlements. An additional complication arises from the fact that it remains unclear how Stage 3 of EMU might catalyze demonstration effects across national borders. Moreover, the presence of a variety of national bargaining frameworks creates the potential for long-lasting wage spillovers effects and protracted period of wage pressures.

Against this background, how have real labor costs and productivity rates evolved within the last few years and what developments are envisaged for the future?

The table provides actual and projected rates of compensation and productivity growth for the euro area from the EU Commission's fall forecasts. Given subdued inflation real compensation rates bave been kept in check in the euro area over the last few years, and for the most part, have remained below the increases in labor productivity. Furthermore, although compensations are expected to increase in real terms over 2000-01, a cyclical pickup in productivity growth is anticipated to offset any inflationary pressures emanating from the labor market. (A similar productivity behavior appears in the OECD forecast and, for manufacturing in the WEO).

Table 1. Lab or Market Developmente

\begin{tabular}{|c|c|c|c|c|c|}
\hline & \multirow[b]{2}{*}{1997} & & \multirow{2}{*}{$\begin{array}{c}\text { Eabiate } \\
1999\end{array}$} & \multicolumn{2}{|c|}{ Forecasts } \\
\hline & & 1998 & & $20 \overline{0} 0$ & 2001 \\
\hline Nosthal conpontation & \multicolumn{3}{|c|}{ (percontage chenga on preceding year) } & & \\
\hline Sertneny & 1.4 & 1.4 & 2.6 & 3.1 & 2.3 \\
\hline Frine: & 2.7 & 2.4 & 2.1 & $\mathbf{2 . 1}$ & 2.3 \\
\hline Itally & 4.2 & -1.5 & 2.3 & 2.4 & 2.5 \\
\hline span & 2.5 & 2.9 & 2.4 & 2.6 & 2.7 \\
\hline Eure aren & 2.1 & 1.5 & 2.5 & 2.4 & 2.6 \\
\hline Prodectivlty grenth & \multicolumn{3}{|c|}{ (perrentage ahange on precediag year) } & & \\
\hline Gerratay & 2.3 & 1.8 & 1.3 & 2.3 & 2.4 \\
\hline France & 1.7 & 20 & 1.3 & 1.5 & 1.6 \\
\hline It ily & 1.4 & 0.6 & 0.3 & 1.4 & 1.6 \\
\hline Spain & 1.0 & 0.3 & o.d & 1.0 & 1.1 \\
\hline Eure ar on & 1.6 & 1.4 & 1.1. & 1.7 & 1.8 \\
\hline
\end{tabular}

Source: BU Commision.

These projections seem in line with earo-area wage negotiations so far in 2000. In Germany, the initial demands of the metal and engineering trade unions are for wage increases of about 5.5 percent-slightly less than last year's initial wage demands, which resulted in a 4.2 percent actual wage hike. The wage demands of other unions are on the order of $4 \frac{1}{2}-5$ 1/2 percent. As for the public sector, trade unions have not yet tabled their requests, but the government appears to stand finm on its proposal (not yet approved by Parliament) for a wage increase in line with inflation (at about 1 percent). The banking sector recently agreed on wage increases of about 3 percent for the year. In France, negotiations on the implementation of the 35-hour workweek are taking center stage and wage discussions are not figuring prominently in the negotiations. Current forecasts are for a $2 \frac{1}{2}$ percent wage increase for 2000 , in line with the 1999 outturn. In Italy, there have not yet been urion demands to renegotiate the two-year bellwether metal workers' agrement struck last year (with wage increases of about 2 percent). In other private sectors, wage demands run in the 2 percent range, and public sector pages will be renegotiated at end Jume. In Spain, the two main labor unions have announced that they will seek wage increases of 3 percent (compared with actual $21 / 4$ percent increases last year). On current WEO projections, ULCs for the group of countries in the table are expected to increase by about 0.7 percent in 2000 and 2001 . 
which they regarded as unsuited to the euro area at this point. ${ }^{10}$ Accordingly, they would manage the publication process so that market participants and the public at large would not erroneously infer a departure from the current "two-pillar" monetary policy strategy.

16. In discussing some institutional and operational aspects of EMU, ECB officials defended the current reliance on a fixed-rate axction format in the ECB tender mechanism, on the grounds that it helped the Eurosystem signal its view on the approptiate level of interest rates, and, in their judgement, exploited superior information on liquidity requirements. ${ }^{11}$ As for financial crisis management, ECB officials stressed that procedures had been put in place for the provision of emergency liquidity assistance, including mechanisms for coordination with national central banks. ${ }^{12}$

17. In response to questions by the mission, ECB representatives underscored that the introduction of the single currency was having a far-reaching impact on the euro-area financial structure. Under the new monetary regime, the national money markets had become better integrated, and some large market participants were expanding the scope of their operations to a pan-European scale, thus quickening the pace of financial sector consolidation. ${ }^{13}$ In the capital markets, developments had been colored by a growing reliance on direct finance as a source of capital. Euro-denominated bond issues had surged in the wake of an acceleration in merger and acquisitions activity in the area, and a growing number of firms had opted to list on local stock exchanges, some of which had emerged as effective venues to mobilize venture capital.

\footnotetext{
${ }^{10}$ In the officials' view, the uncertainties surrounding the regime change and the lack of conclusive empirical evidence on the monetary transmission process in the euro-area militated against the use of a formal inflation targeting framework, (see Angeloni, I., Gaspar, V., and o. Tristani: "The Monetary Policy Strategy of the ECB," in D. Cobham and G. Zis (eds.) From EMS to EMU, 1999).
}

${ }^{11}$ The staff's argument for widening the scope of variable-rate auctions is spelled out in Annex 1 of the International Capital Markets Report, 1999. This may be found at http://www.img.org/external/pubs/tt/icm/1999/index.ftm.

${ }^{12}$ The main guiding principles for crisis management procedures agreed within the Eurosystem are described Annex 1 of the International Capital Markets Report, 1999.

${ }^{13}$ The number of monetary and financial institutions in the area as a whole declined by some 4 percent in 1999. 


\section{B. The Exchange Rate}

18. The discussion of exchange rate developments focused on the implications of the euro's steady depreciation. By the time of the mission, the currency was about 14 percent below its value at the beginning of the year against the U.S. dollar and 23 percent against the Japanese yen. On a multilateral basis, the euro had depreciated by about 12 percent since its introduction, both in nominal and (unit labor cost-based) real effective terms. As a result, the real effective exchange rate was at a decade low, about 13 percent below its average value in the 1990s. In late January and early February 2000 , the euro weakened further (by some $2 \frac{1}{2}$ percent on a multilateral basis), with the bilateral rate vis-à-vis the U.S. dollar falling below parity.

19. There was agreement in the discussions that the euro was considerably weaker than justified by medium-term fundamentals - with the staff's latest assessment based on a savinginvestment approach suggesting that the undervaluation was on the order of 10 to 20 percent in effective terms and 30 percent or more against the U.S. dollar. ${ }^{14}$ Therefore, as the euro-area economy was entering a phase of robust expansion, an appreciation was expected and desirable on both cyclical and longer-run considerations, including those regarding the large current and capital account imbalances among major currency blocs. The staff noted that such strengthening would help dampen inflationary pressures and lessen the need for explicit interest rate actions.

20. There was also agreement that the depreciation of the euro vis-à-vis the U.S. dollar was in part the reflection of the remarkably strong performance of the U.S. economy (Figure 4), as well as of an unwinding of earlier "europhoria" about the prospective role of the euro in international reserves. In addition, the weakness of the euro was seen to reflect the large outflows of foreign direct and portfolio investment from the euro area and the equally large inflows into the U.S. economy, which more than offset the imbalances in current account transactions (Box 5). These flows denoted a certain skepticism on the part of investors on the potential for non-inflationary growth in the euro area, at least by comparison with the United States. This suggested that confidence-boosting inroads into fiscal and structural reform could facilitate a turnaround in the exchange rate. In the mission's view, there was also some evidence that market participants had placed considerable weight on developments in the largest euro-area countries that seemed to substantiate doubts about governments' will to implement structural reforms.

21. In discussing the policy implications of the euro's weakness, the ECB representatives noted that, given the absence of an exchange rate target in the monetary framework, the deprectation mattered only to the extent that it translated into a risk to medium-term price stability. At the time (December 1999), this risk was not yet regarded as serious-an

${ }^{14}$ The Commission considered that the degree of undervaluation was somewhat less. 
Figurc 4. Rolling Forecasts for 1999 GDP Growth and the Euro-U.S. Dollar Exchange Rate.

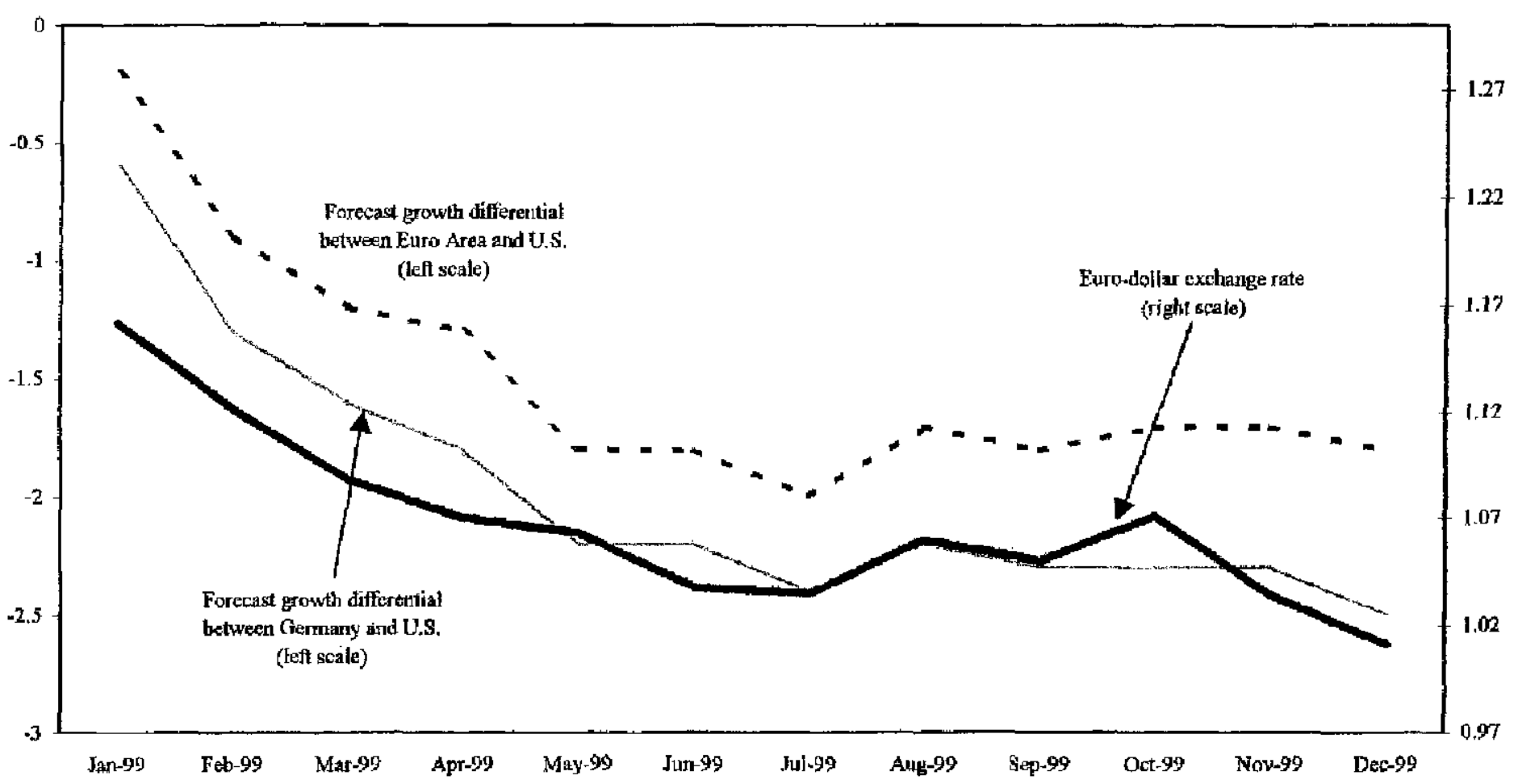

Source: Consensus Economics. 


\section{Box 5. Euro-Area, U. S., and U. K. Capital Flows}

Intenrational capital flows are notoriously difficult to estimate ard interpret. In the case of the euro-area, severe data limilations - especially the lack of data harmonization across euro-area countries and huge discrepancies between banking and national account data-further complicate the analysis. This said, the table below provides some striking data.

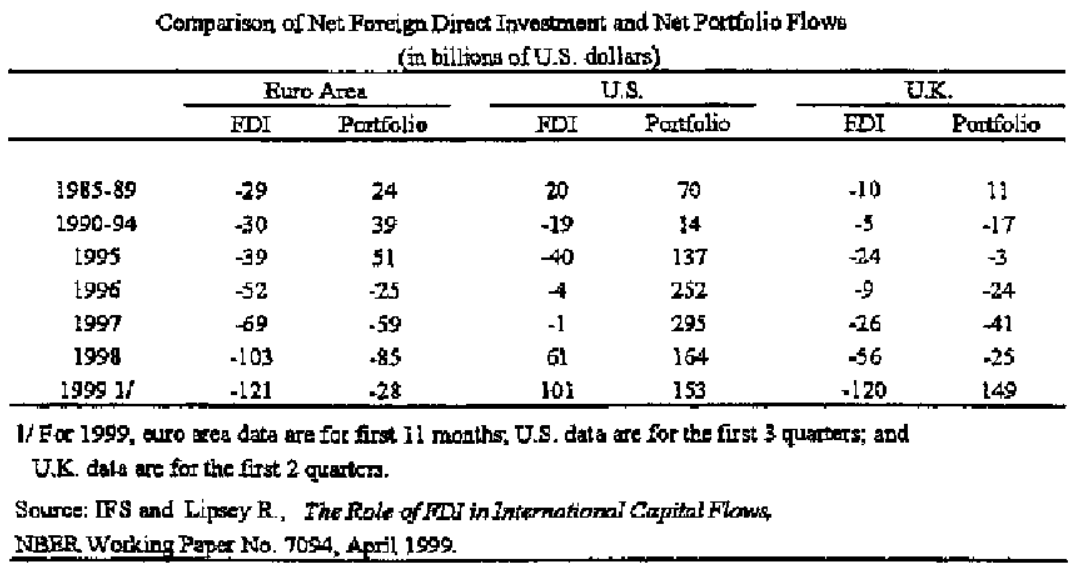

- For most of the last fifteen years, the euro area has been the source of a steady net outflow of foreign direct investment (FDI). Through the 1990s, however, its role as a net supplier of FDI capital appears to have grown, with net FDI outflows exceeding US\$100 billion in 1998 and 1999 . Some exceptional and "one-off" transactions (e.g. the Daimler-Chrysler merger and new important acquisitions by Deutsche Bank in the United States) might have contributed to the FDI outflows in those two years. However, they are far from explaining the increase in those outflows. By contrast, the United States has, for the first time in many years, benefited from large net inflows of FDI in 1998-99.

- The table also shows that, after some ten years as a net recipient of portfolio investment, the euro area became a net supplier in the mid-1990s-as interest rates spread between dollar- and (synthetic) eurodenominated assets started to widen. In contrast, there has been a marked rise in portfolio inflows into the United States in the second half of the 1990s.

The size of these flows, which swamp measured current account imbalances, suggests that they might be contributing to the euro's weakness. Whether they reflect the more favorable cyclical position of the United States, the extraordinary performance of its equity markets, or lack of investors' confidence in the euroarea prospects is, however, barcer to infer, although it is difficult to nile out completely the latter interpretation, giver the steepening of the euro-area yield curve. 
assessment shared by the Commission and the EFC members. ${ }^{15}$ The ECB officials aiso thought that it would be a mistake to try to support the exchange rate by increasing the refinancing rate in the absence of risks to price stability in the euro area. In their view, such a move could even be counterproductive, if it were perceived by markets as endangering the recovery. On January 31 , the Euro-11 Ministers and the ECB stated commonly that "a strong economy goes along with a strong currency."

22. The mission agreed that the weakness of the currency posed no immediate threat to medium-term price stability and that an increase in interest rates would not be an appropriate response ${ }^{16}$ It noted, however, that the broader effects were far from benign, as they jeopardized an orderly resolution of global imbalances. In fact, while a weakening euro had helped in the initial phases of the recovery, the lagged response of trade flows to a continuing depreciation would exacerbate the current pattern of trade imbalances even as the cyclical positions of the United States and the euro area converged. ${ }^{17}$ Moreover, large and growing exchange rate misalignments carried the risk of sharp and disorderly corrections. Therefore, supporting the euro through more growth-enhancing structural reforms was called for on both international and domestic grounds.

23. Following the further weakening of the currency in late January and early February, the ECB's view on the implication of a sliding euro for medium-term price stability has evolved. In explaining the rationale for the monetary tightening of early February, in fact, the ECB Governing Council noted that, given the magnitude and the duration of the depreciation, import prices could be expected to increase further, thereby raising concerns of a lasting

${ }^{15}$ The Commission staff estimates that a 10 percent depreciation of the euro sustained for two years increases headline inflation by some $1 / 2$ of 1 percent each year. See The EU Economy 1999 Review, November 1999.

${ }^{16}$ Both the staff and ECB officials were concerned that an increase in interest rates in the absence of risks to price stability could reduce the desirability of euro-area equities because of the negative effect on expected earnings. If this effect dominated the more classical effect on bonds, the exchange rate-as a price that settles at a level that makes investors content to hold their euro assets--would depreciate. In contrast, an increase in interest rates that is viewed by market participants as enhancing the sustainability of an economic expansion would most likely have the opposite effect.

${ }^{17}$ The mission noted, in particular, that the current account surplus for the euro area (about 1 percent of GDP) was sizable given that the aggregate current account for all industrialized countries was in significant deficit (about $1 / 2$ of 1 percent of GDP). However, statistics on the external position of the euro area are still being refined by Eurostat and current account data are subject to considerable uncertainty. 
upturn in headline inflation. As argued in paragraph 13 above, the staff does not fully share the ECB's assessment of medium-term inflationary pressures.

\section{Fiscal Policy}

24. With the improved outlook for the recovery, the fiscal discussion was mostly concerned with the medium-term orientation of policy. Preliminary estimates for 1999 indicated that virtually all euro-area countries had met-and in some cases exceeded-their budgetary targets, aften on the strength of better-than-expected revenue performance and notwithstanding slower growth than initially projected (Table 1). The mission and representatives of the ECB, the Commission, and at the EFC agreed that this development was indicative of governments' commitment to safeguard hard-won credibility, as well as of the effectiveness of mechanisms for fiscal policy coordination and surveillance, which had been bolstered by a constructive exercise of peer pressure-notably in the fora provided by ECOFT, the Euro-11 Group, and the EFC. ${ }^{18}$

25. However, the mission stressed that the achievement of the fiscal objectives in 1999 also bore witness to the lack of ambition of the targets and the excessive reliance on safety margins in the elaboration of the budgets. Indeed, in comparison with 1998, the area-wide cyclically adjusted primary surplus had improved only marginally, while tax pressure (broadly defined as the revenue-to-GDP ratio) had increased by $1 / 3$ of 1 percent of GDP. As a result, 1999 had marked the second consecutive year of little adjustment effort-defined as the sum of the reductions in the deficit and in the tax burden-after the sizable fiscal consolidation in the run-up to Stage 3 of EMU. Against this backdrop-and in light of the favorable setting provided by the improved economic outlook and the supportive monetary stance-the mission thought it urgent to restore the momentum of consolidation, lest the opportunity be missed to put the public finances on a sustainable footing and reduce the high tax burden, especially on labor, which inhibited economic performance in most euro-area countries. This view was shared by ECB officials.

26. The mission noted that a more forceful drive to lower tax rates was indeed evident in the 2000-03 fisca: plans of several countries. Capitalizing on the 1999 revenue overperformance, which reflected inter alia a welcome improvement in the efficiency of tax administration, France, Germany, and Italy-among others-were aiming for meaningful reductions in tax rates. However, countries had generally maintained their previous targets for both the fiscal balance and the revenue ratio-with the reduction in tax rates being compensated by an effective broadening of the base. Therefore, in spite of the planned tax cuts, tax burdens remained very high and for the area as a whole the revenue ratio was

\footnotetext{
${ }^{18}$ The effectiveness of peer pressure and surveillance has been underpinned in the area of fiscal policy, unlike in the structural areas, by the relative ease in monitoring quantified targets.
} 
Table 1. Euro Area. Staff Medium-Term Fiscal Projections

(General government, in percent of GDP unless otherwise noted)

\begin{tabular}{|c|c|c|c|c|c|c|}
\hline & 1998 & $\begin{array}{r}\text { Est. } \\
1999 \\
\end{array}$ & $\begin{array}{l}\text { Proj. } \\
2000 \\
\end{array}$ & $\begin{array}{l}\text { Proj. } \\
2001 \\
\end{array}$ & $\begin{array}{l}\text { Proj. } \\
2002 \\
\end{array}$ & $\begin{array}{l}\text { Proj. } \\
2003 \\
\end{array}$ \\
\hline Revenue & 46.8 & 47.1 & 46.6 & 45.9 & 45.6 & 45.5 \\
\hline Expenditure & 48.8 & 48.5 & 47.5 & 46.7 & 46.0 & 45.6 \\
\hline o/w interest payments & 4.8 & 4.4 & 4.1 & 3.9 & 3.8 & 3.7 \\
\hline Overall balance & -2.1 & -1.2 & -0.9 & -0.8 & $-0,4$ & -0.1 \\
\hline Structural balance & -1.1 & -0.4 & -0.4 & -0.5 & -0.4 & -0.2 \\
\hline Primary balance & 2.2 & 2.6 & 2.8 & 2.7 & 3.0 & 3.1 \\
\hline Prinary structural balance & 3.2 & 3.5 & 3.3 & 2.8 & 2.9 & 2.9 \\
\hline \multicolumn{7}{|l|}{ Mernorandum items: } \\
\hline \multicolumn{7}{|l|}{ Change in primary structural balance } \\
\hline (in percent of potential GDP) & $\ldots$ & 0.3 & -0.3 & -0.5 & 0.0 & 0.0 \\
\hline \multicolumn{7}{|l|}{ Primary structural expenditure } \\
\hline (real percent change) & $\ldots$ & 2.8 & 1.8 & 1.9 & 1.8 & 1.8 \\
\hline Gross debt & 75.0 & 73.4 & 71.2 & 69.1 & 66,9 & 64.9 \\
\hline Real GDP (percentage change) & 2.8 & 2.2 & 3.1 & 3.2 & 2.9 & 2.6 \\
\hline GDP deflator (percentage change) & 1.7 & 1.3 & 1.5 & 1.6 & 1.5 & 1.4 \\
\hline
\end{tabular}

Sources: WEO; and Fund staff calculations. 
projected to decline only by $1 \frac{1 / 3}{3}$ percent of GDP berween 1998 and 2003. Moreover, the 2000-03 fiscal plans envisaged hittle aggregate deficit reduction on a cyclically adjusted basis and, with propitious prospects for area growth, would imply a pro-cyclical fiscal stance in the near term (Table 1). ${ }^{19}$

27. In the staff's opinion, the general medium-term orientation of fiscal policy in most euro-area countries (as reflected in their updated Stability Programs (Table 2)) still fell short of what was needed in order to: (i) create room for the operation of automatic stabilizersand for discretionary fiscal policy if needed; (ii) make provisions for implicit public debts and for the budgetary implications of population aging, ${ }^{20}$ and (iii) allow for a meaningfil reduction in the euro-area tax burden (Figure 5 and Box 6). Achieving these goals would require a more ambitious reduction in public spending.

28. More precisely, the mission argued that all euro-area countries could and should aim to achieve balance or a surplus by 2003 , as well as sufficient tax cuts to reduce the area-wide revenue ratio by at least 2 percent of GDP from its 1998 level-thus bringing it down to what it was before the tax hikes in the run-up to Stage 3 of EMU. The degree of required adjustment, its timing, and the allocation of the yield from spending restraint would, of course, vary across countries in line with their different cyclical positions and debt levels. While officials at the ECB and the Commission appeared to favor a rapid attainment of sustainable fiscal positions, the mission thought that equal weights should be attached to deficit and tax reductions, on the grounds that an early reduction in tax rates in most countries would catalyze favorable supply-sicie responses in the medium term and would help to generate political support for fiscal consolidation. Moreover, it would be preferable to reduce taxes at a time when the output gap was still sizable.

29. Attention should also be paid to the quality of the adjustment. On the revenue side, steps in the right direction were being taken in several countries with a pre-commitment to a timetabie of tax cuts, notably on labor income, as in the case of Germany-aithough more remained to be done. As regards public spending, progress had been more uneven and less encouraging. On the positive side, the mission welcomed in particular the selective cuts on subsidies and public consumption envisaged in Germany's medium-term program, as well as

${ }^{19}$ For 2000 , the staff projects an unchanged structural balance for the area as a whole, with the primary structural surplus declining by about $1 / 4$ of 1 percent of aggregate GDP.

Furthermore, the area-wide revenue-to-GDP ratio is projected to fall only marginally below its 1998 level.

${ }^{20}$ Primary expencitures as a percent of GDP are projected to increase by between 2 and 6 percentage points in euro-area countries over the next 30 years as a result of population aging. 
Table 2. Euro Area: Overall Balances and Revenue Ratios under the Old and the New Stability Programs, and Corresponding Staff Projection

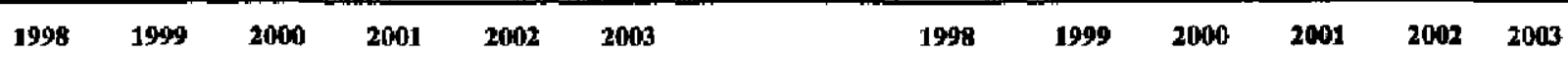

\section{Overall balanse}

1999 Stabilly Programs $1 /$

\begin{tabular}{|c|c|c|c|c|c|c|}
\hline Euro-aren & -2.3 & $\underline{-1.8}$ & -1.5 & $-1,1$ & $\underline{-0.6}$ & ... \\
\hline Auntria & -2.2 & -2.0 & -1.7 & -1.5 & -1.4 & $\ldots$ \\
\hline Belginm & -1.6 & -1.3 & -1.0 & -0.7 & -0.3 & $\ldots$ \\
\hline Finland & 1.0 & 2.4 & 2.2 & 2.1 & 2.3 & $\ldots$ \\
\hline Franee & -2.9 & -2.3 & -1.7 & -1.3 & -0.8 & $\ldots$ \\
\hline Germany & -2.5 & -2.0 & -2.0 & -1.5 & -1.0 & $\ldots$ \\
\hline Ireland & 1.7 & 1.7 & 1.4 & 1.6 & 1.2 & $\cdots$ \\
\hline Italy & -2.6 & -20 & -1.5 & -1.0 & -0.3 & $\ldots$ \\
\hline Netherlands & -1.3 & -1.4 & -1.2 & -1.2 & .1 .1 & $\ldots$ \\
\hline Portugal & -2.3 & -20 & -1.5 & -1.2 & -0.8 & $\ldots$ \\
\hline \multirow[t]{2}{*}{ Spain } & -1.9 & -1.6 & -1.0 & -0.4 & 0.0 & $\ldots$ \\
\hline & \multicolumn{6}{|c|}{2000 Stability Programs $2 /$} \\
\hline Elurto-area 37 & -2.1 & $\underline{-1.4}$ & $\underline{1.1}$ & $\underline{-1.0}$ & $\underline{-0.5}$ & $\underline{-0.1}$ \\
\hline Anstria & $\ldots$ & $\ldots$ & $\ldots$ & $\ldots$ & $\ldots$ & $\ldots$ \\
\hline Belgium & -1.0 & -1.1 & -1.0 & -0.5 & 0.0 & 0.2 \\
\hline Pivaland & 1.4 & 3.1 & 4.7 & 4.2 & 4.6 & 4.7 \\
\hline Franse 4 & -2.7 & -2.1 & -1.7 & -1.2 & -0.8 & -0.3 \\
\hline Germany $5 /$ & -1.7 & -1.2 & -1.0 & -1.5 & .1 .0 & -0.5 \\
\hline Ireland $6 /$ & 2.1 & 3.2 & 3.3 & 2.8 & 29 & 2.9 \\
\hline Italy & -2.8 & -2.0 & -1.5 & -1.0 & -0.6 & -0.1 \\
\hline Netheriands $6 /$ & -0.8 & -0.6 & -0.6 & -1.3 & -1.1 & -1.1 \\
\hline Portugal & $\ldots$ & $\ldots$ & $\ldots$ & $\ldots$ & $\ldots$ & $\ldots$ \\
\hline Spain & -2.3 & -1.3 & -0.8 & -0.4 & 0.1 & 0.2 \\
\hline
\end{tabular}

1999 Stability Programs \$/

$\begin{array}{lllllll}\text { Eurn-area } & \mathbf{4 7 . 2} & \mathbf{4 6 . 9} & \mathbf{4 6 . 4} & \mathbf{4 6 . 2} & \mathbf{4 5 . 9} & \ldots \\ \text { Aumtria } & \mathbf{4 8 . 1} & \mathbf{4 8 . 1} & \mathbf{4 7 . 9} & \mathbf{4 7 . 8} & 47.6 & \ldots \\ \text { Belgium } & \mathbf{4 7 . 0} & 46.7 & 46.4 & \mathbf{4 6 . 1} & 45.9 & \ldots \\ \text { Finfand } & \mathbf{5 2 . 1} & 50.7 & 49.8 & \mathbf{4 9 . 3} & 48.7 & \ldots \\ \text { France } & \mathbf{5 1 . 4} & 51.2 & 50.8 & 50.3 & 49.8 & \ldots \\ \text { Germany } & 46.0 & 45.5 & 44.5 & 44.5 & 44.0 & \ldots \\ \text { Ireland } & 35.1 & 34.5 & 33.8 & 33.3 & 32.7 & \ldots \\ \text { Italy } & 47.7 & 47.4 & 47.5 & 47.2 & 47.4 & \ldots \\ \text { Netherlands } & 48.0 & 47.7 & 47.0 & 46.2 & 45.5 & \ldots \\ \text { Partugal } & 44.0 & 44.6 & 44.6 & 44.9 & 45.1 & \ldots \\ \text { Spain } & 41.6 & 41.4 & 41.2 & 41.2 & 41.2 & \ldots\end{array}$

2000 Stability Programs $2 /$

$\begin{array}{lrrrrrr}\text { Eura-area 3/ } & \mathbf{4 6 . 7} & \underline{47.1} & \underline{46.6} & \underline{45.8} & \underline{45.5} & \frac{45.2}{\ldots} \\ \text { Austria } & \ldots . & \ldots . . & \ldots & \ldots & \ldots & \ldots \\ \text { Belgium } & 46.4 & 46.4 & 45.8 & 45.5 & 45.4 & 45.2 \\ \text { Finland } & 51.1 & 51.2 & 51.4 & 50.4 & 49.9 & 49.3 \\ \text { France 4/ } & 51.2 & 51.8 & 51.3 & 50.9 & 50.5 & 50.1 \\ \text { Germany 5/ } & 46.6 & 47.3 & 46.5 & 45.0 & 45.0 & 44.5 \\ \text { Ireland 6/ 7/ } & 35.9 & 35.5 & 35.0 & 34.1 & 33.6 & 33.6 \\ \text { Italy } & 46.5 & 46.7 & 46.3 & 45.8 & 45.3 & 44.9 \\ \text { Netherlands 6/ } & 44.3 & 44.6 & 43.7 & 42.3 & 42.0 & 42.0 \\ \text { Portugal } & \ldots & \ldots & \ldots . & \ldots . & \ldots & \ldots \\ \text { Spain } & 39.9 & 40.1 & 40.1 & 40.0 & 39.9 & 39.8\end{array}$

Acturl

StafrProjections $\mathbf{~}$

\begin{tabular}{|c|c|c|c|}
\hline$-2,0$ & $\underline{-1.8}$ & $\underline{-1.3}$ & $\underline{-0.9}$ \\
\hline-22 & -2.0 & -2.6 & -2.3 \\
\hline-0.9 & $-1,1$ & -0.6 & -0.4 \\
\hline 1.4 & 3.1 & 4.4 & 4.8 \\
\hline-28 & -2.4 & -2.1 & -1.5 \\
\hline+20 & -2.2 & -1.4 & -1.1 \\
\hline 2.4 & 2.7 & 2.2 & 20 \\
\hline-2.7 & -2.3 & -1.7 & -1.2 \\
\hline-0.7 & -0.3 & 0.3 & -0.6 \\
\hline-2.2 & -1.6 & -1.4 & -1.3 \\
\hline
\end{tabular}

Actual Estimate

Staft Projections 2f

\begin{tabular}{|c|c|c|c|c|}
\hline$\underline{2.1}$ & $\underline{-1.2}$ & -0.9 & $=0.7$ & -0.3 \\
\hline$\ldots$ & $\ldots$ & $\ldots$ &.- & ... \\
\hline-1.0 & -0.9 & -0.5 & -03 & 0.0 \\
\hline 1.4 & 3.1 & 4.6 & 49 & 5.1 \\
\hline-27 & -1.8 & -1.4 & -1.0 & -0.5 \\
\hline-1.7 & -1.2 & -0.8 & -1.0 & -0.4 \\
\hline 21 & 3.2 & 3.3 & 2.8 & 2.9 \\
\hline-2.8 & -1.9 & -1.7 & -1.2 & -1.1 \\
\hline$-0,8$ & 0.5 & 0.4 & -0.3 & 0.1 \\
\hline ... & $\ldots$ & $\ldots$ & ... & \\
\hline & -1.1 & -0.8 & -0.4 & \\
\hline
\end{tabular}

Revenue ratio

Actual

Staft Projections $1 /$

$\begin{array}{lllll}\mathbf{4 6 . 9} & \mathbf{4 7 . 2} & \mathbf{4 6 . 8} & \mathbf{4 6 . 4} & \mathbf{4 6 . 0} \\ \mathbf{4 7 . 4} & \mathbf{4 7 . 0} & \mathbf{4 6 . 4} & \mathbf{4 6 . 4} & \mathbf{4 6 . 3} \\ \mathbf{4 6 . 9} & \mathbf{4 6 . 7} & 46.5 & 46.3 & 45.9 \\ 51.2 & 51.2 & 51.1 & 50.5 & 50.2 \\ 52.2 & 52.5 & 52.0 & 51.4 & 51.2 \\ \mathbf{4 5 . 4} & 45.8 & 45.6 & 45.2 & 44.8 \\ 35.7 & 36.1 & 35.8 & 35.4 & 35.1 \\ 47.0 & 47.4 & 46.6 & 46.4 & 45.6 \\ \mathbf{4 8 . 1} & \mathbf{4 8 . 5} & 47.9 & 46.3 & 45.8 \\ 43.4 & 44.5 & 44.5 & 44.4 & 44.4 \\ 40.3 & 40.3 & 40.2 & 40.2 & 40.3\end{array}$

Actuai Estimate

Staft Projections 2 2

$\begin{array}{rrrrrr}\frac{46.7}{\ldots} & \frac{47.2}{\ldots} & \underline{46.6} & \underline{45.9} & \underline{45.6} & \underline{45.4} \\ 46.4 & 46.3 & 45.2 & 44.7 & 44.5 & 44.1 \\ 51.1 & 51.2 & 51.2 & 50.6 & 50.3 & 49.7 \\ 51.2 & 52.0 & 51.6 & 51.0 & 50.6 & 50.3 \\ 46.6 & 47.3 & 46.6 & 45.4 & 45.6 & 45.4 \\ 34.1 & 34.1 & 33.7 & 32.8 & 32.6 & 32.0 \\ 46.5 & 46.9 & 46.1 & 45.7 & 45.0 & 44.7 \\ 44.3 & 45.7 & 44.7 & 42.9 & 42.4 & 42.1 \\ \ldots & \ldots . & \ldots . & \ldots & \ldots & \ldots \\ 39.9 & 40.0 & 39.7 & 39.7 & 39.6 & 39.6\end{array}$

Sourcer: National Authorities' Stability Programs; and Fund staff projections. 1/ Dxta based on ESA79. Staff projections as of early 1999.

2/ Dala baked on ESAQS. Staff projections as of end-January 2000.

3/ The average excludes Austria and Portugal.

4/ Figures for 2001 and 2002 are atsff interpolations.

5/ Based on the revised German Stability Program.

6/ The country's Stability Program only goes to 2002. The overall balanee and revenue ratio are assumed unchanged in 2003.

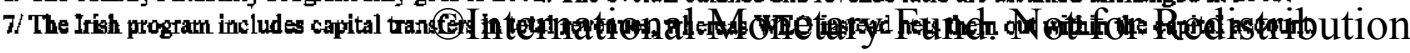


Figure 5. Fiscal Perspectives in the Euro Area (In percent of GDP) 1 /
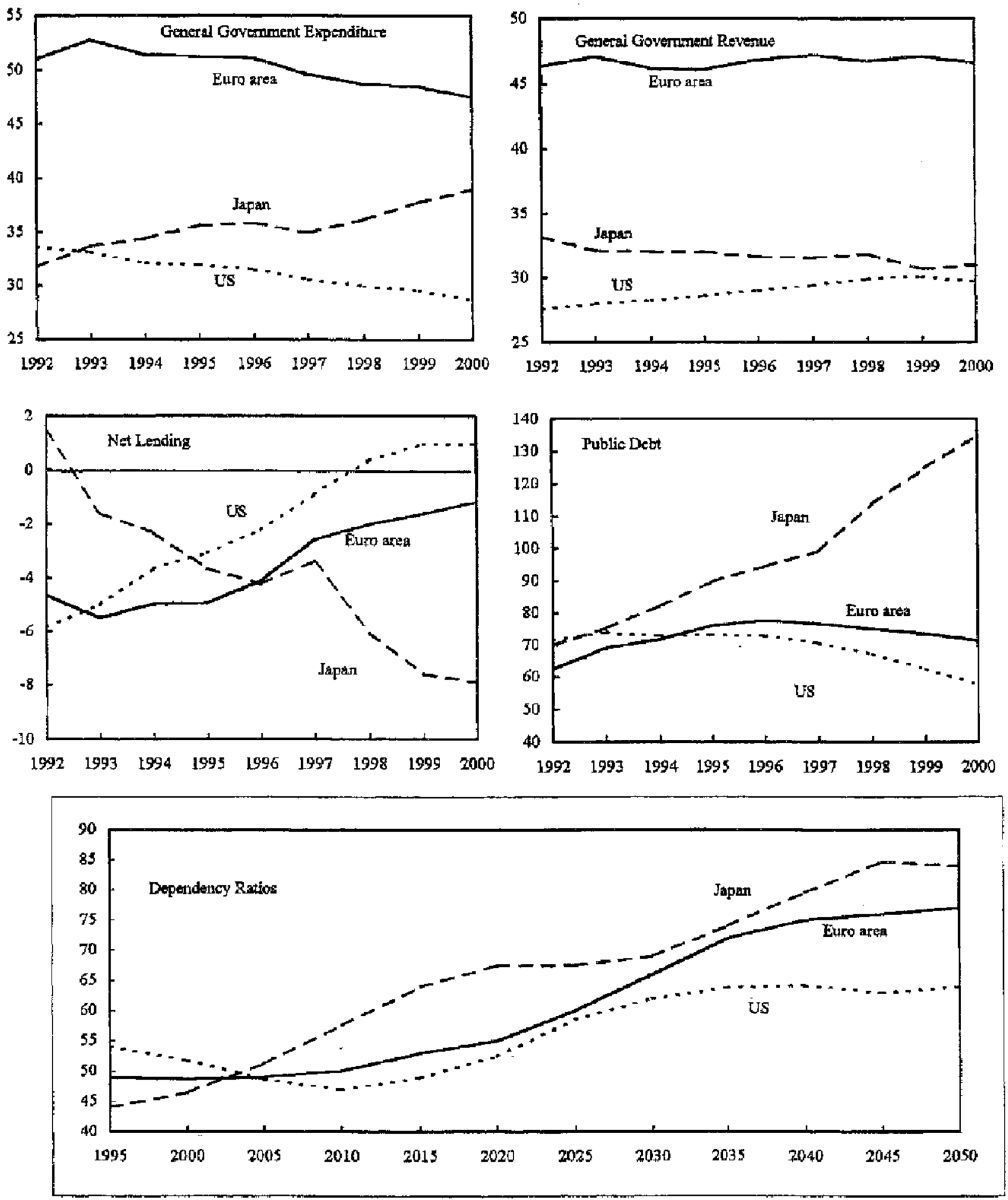

Sources: WEO and OECD.

1/ The top 4 panels are in percent of GDP; in the bottom panel the dependency ratio is defined as population younger than 14 and over 65 years of age, as a percent of working age population. 


\section{Box 6. Euro Area: The Updated Stability Programs}

In the framework of intra-EU multilateral surveillance of national fiscal policies, member states have submitted updated Stability or Convergence Programs to the European Commission, for later evaluation by the ECOFIN council. In all cases but one, the new Stability Programs at least maintain previous deficit objectives through 2002 , and for countries that have submitted plans beyond that date, further consolidation in 2003 is envisaged. For the euro area as a whole, the revenue ratio is now projected to decline by $13 / 4$ percent of aggregate GDP oyer $2000-02$, compared with a reduction of 1 percent of GDP scheduled in the old Stability Programs. However, the change can be traced to the larger-than-expected revenues in 1999.

Eurv area: Charges in fiacal indientors betwoen 1098 and 2002.

\begin{tabular}{|c|c|c|c|c|}
\hline & \multicolumn{2}{|c|}{ Overalt balance } & \multicolumn{2}{|c|}{ 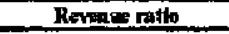 } \\
\hline & $199 \mathrm{SP}$ & $2000 \mathrm{SP}$ & $1599 \mathrm{SP}$ & 20005 \\
\hline Drusane & 1.7 & 15 & $-1,2$ & $-1,2$ \\
\hline Anerria If & 0.8 & 18 & .0 .3 & -0.3 \\
\hline Bdgium & 1.3 & 1.0 & -1.1 & -1.2 \\
\hline Finlend & 13 & 3.2 & .3 .4 & -1.3 \\
\hline Pruser & 21 & 1.9 & -1.6 & -1.0 \\
\hline Gemoung & 1.5 & 0.7 & -2.0 & $-\mathrm{L} 6$ \\
\hline kedend & -0.5 & 6.8 & -2.4 & .2 .3 \\
\hline H.1y & 23 & $\$ 1$ & -0.3 & -1.2 \\
\hline Neftherland & 0.2 & -0.3 & $-2,5$ & +2.3 \\
\hline Pcrtugal if & 1.5 & 1.5 & 1.1 & 1.1 \\
\hline Sprin & 1.9 & 2.4 & $\cdot \theta-4$ & 00 \\
\hline
\end{tabular}

On balance, therefore, the updated Stability Programs do not represent a substantive improvement over their older versions, most of which had been deemed insufficiently ambitious by the European Commission and ECOFIN. In the staff's estimates, the updated programs imply only a reduction in the area-wide structural deficit of 0.7 percent of GDP between 1998 and 2003 . This improvement, however, is more than fully accountea for by a projected decline in interest payments (by 1.1 percent of GDF), thus implying a concomitant deterioration in the structural primary surplus by some $1 / 2$ of 1 percent of GDP. In particular, the staff projects a deterioration in the structural primary balance of the order of $1 / 2$ of 1 percent of GDP in Germany, and more than twice as much in Belgium, Italy and the Netherlands (Figure below.)

Furthermore, the new programs still lack specificity as to the adjustment measures undertying the projections, in particular the quality of the envisaged expenditure cuts, and adjustment appears unduly back-loaded, especially in some peripheral coumtries facing overheating pressures.

A preliminary assessment of the updated Stability Programs indicates that, in the area as a whole, progress toward fiscal sustainability as defined in the framework of the Stability and Growth Pact is not accelerating. More womisonely, since that definition of sustainability does not address prospective demands on the budget coming from population aging and other implicit public liabilities, as well as the need for a meaningful reduction is the euro area's tax pressure, the current fiscal objectives may still remain far from an "appropriate" medium-term fiscal position."

An analysis along these lines is the subject matter of an upcoming staff study. 


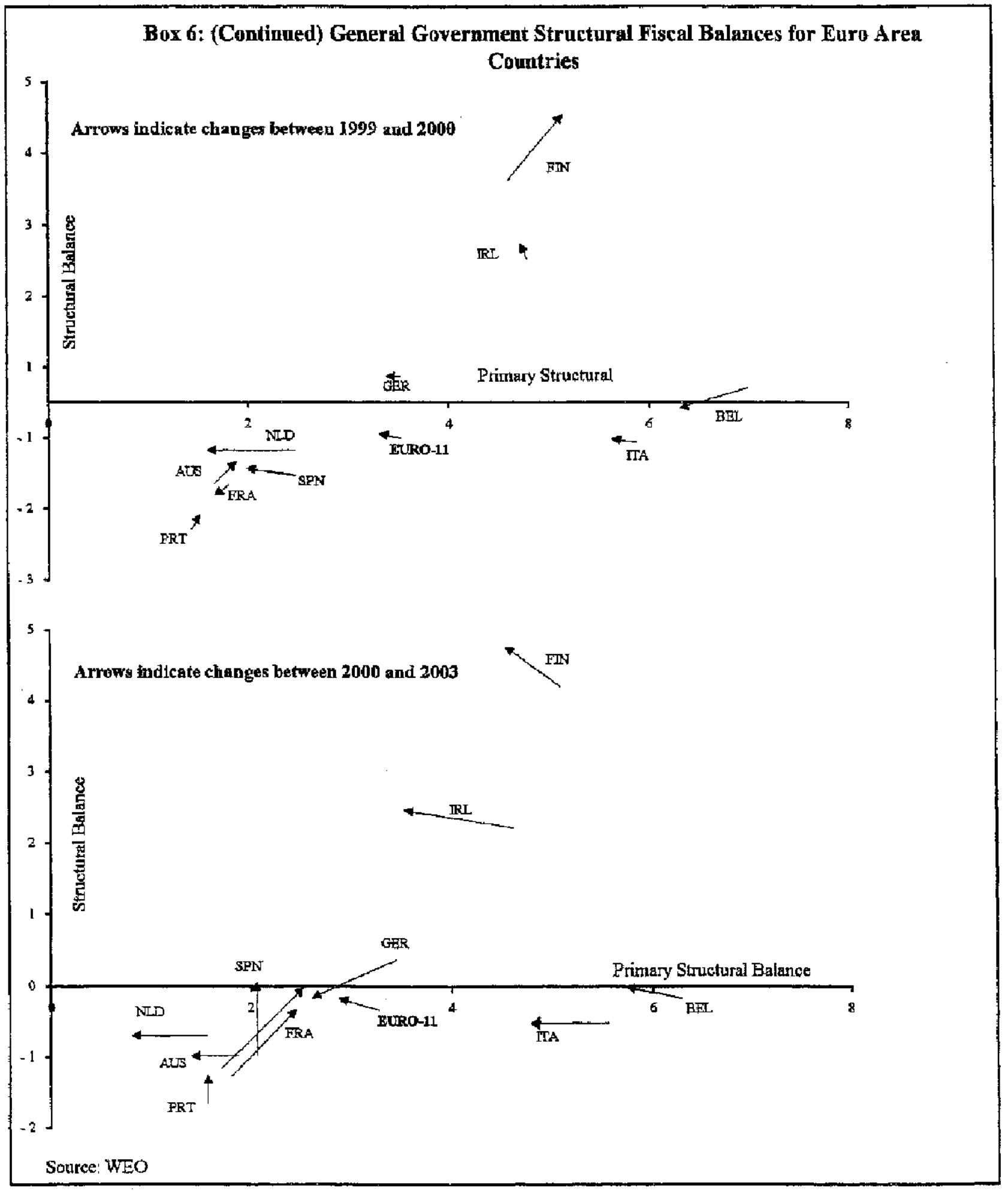

(C) International Monetary Fund. Not for Redistribution 
France's strategy of targeting expenditure growth while allowing the automatic stabilizers to operate on the revenue side. The mission thought, however, that durable spending reductions hinged in most countries on structural reforms in one or more of three key areas: streamlining the civil service (for example, in France, Germany, and Italy), overhauling the healthcare systems (notably, in Italy, France, and Spain), and further reforming pension schemes (still a priority in virtually all euro-area countries).

30. While broadly agreeing with the mission on the appropriateness of further fiscal efforts, Commission representatives noted that (i) gauging the extent of the adjustment with reference only to primary surpluses was overly restrictive, as the reduction in interest payments resulted, at least in part, from enhanced policy credibility and contained therefore an element of structural expenditure reduction; and (ii) most of the updated Stability Programs still relied on conservative assumptions and built-in contingencies, making it likely that fiscal objectives would be overachieved. In addition, EFC nembers pointed to the political difficulties of posting surplus targets that could catalyze additional spending demands in the cabinets and erode broad political support for further welfare system reform.

\section{With respect to the last two points, the mission countered that targeting reasonabiy} ambitious objectives based on realistic assumptions would be the best strategy to ensure fiscal transparency and to focus the public debate on the right priorities. It noted that, although safety margins were desirable, caution in budget preparations ought not to provide an excuse for choosing unambitious targets, and budgetary cushions could lead to accommodation of chronic expenditure slippages rather than their correction. As for the political expediency of not posting bolder fiscal objectives, the mission argued that such a strategy did not appear viable in the longer term, since additional claims on budgetary resources would eventually be staked anyway as better-than-targeted outturns became evident.

\section{Structural Policies}

32. As regards structural policies, all euro-area representatives and the mission agreed that progress in product and labor market reforms was bringing about a significant transformation in the microeconomic structure of the euro area, evidenced by greater market integration and competition, falling utility prices, and increased employment content of economic growth in many countries (for example, through promotion of part-time work and temporary contracts). EFC members noted, however, that public opinion did not yet seem to fully appreciate the extent of this process and policymakers might have to improve communication. In addition, they thought that markets had overreacted to occasional examples of government interference in the economy.

33. The progress to date was attributed in part to the adoption of a common strategy by EU member states and the establishment of EU-wide guidelines and surveillance procedures, as well as institutional fora for the exercise of peer pressure and the identification of best practices, as in the fiscal domain. This had been demonstrated by the helpful role played by the Commission's evaluation of National Action Plans in the framework of the Employment 
Guidelines (Box 7). As for the markets in goods, services, and capital, progress continued to be made in privatization, liberalization, and deregulation, setting the stage for greater competition and market integration. Moreover, single market legislation had been almost fully transposed in most countries, and the more systematic approach to surveillance of structural issues envisaged by the "Cardiff process" was helpful.

34. The mission argued, however, that strengthening in a fundamental way the economic performance of the euro area--thereby contributing to a durable reduction in its stillunacceptabie unemployment rate required additional action to push forward the reform process. In particular, deep-seated labor market rigidities still severely undermined the growth potential of several large euro-area countries-and, by implication, investors' confidence in the area-wide prospects and its currency. As regards the product and service markets, there remained ample scope for promoting market access in still-sheltered sectors (including some public utilities), as well as for reducing government involvement in commercial activities. High priority should also be given to removing obstacles to business start-ups and to employment creation in services,

35. More specifically, the mission stressed that the commonly agreed reform strategy at the EU level still suffered from both implementation and conceptual gaps. On the implementation front, there was a need to (i) strengthen intra-EU multilaterai surveillance and enforcement of existing directives beyond the minimum acceptable level; (ii) broaden the scope of the economic policy guidelines (inter alia, to encompass evaluations of national welfare systems); and (iii) add specificity to existing guidelines for product and labor market reform. As for the conceptual content of the strategy, substantive reductions in structural rates of unemployment (rather than in its cyclical component) would materialize only once politically sensitive issues (related to the eligibility for social assistance and the need for greater wage and labor cost differentiation across regions and skill levels) had finally been tackled, and better targeted active labor market policies had been implemented (see Table 3).

36. The mission elaborated this last point, by arguing that:

- Unemployment assistance played a key role in improving the matching process in the labor market and thus increased allocative efficiency, but-by raising the reservation wage of the jobless-it often weakened the incentive to seek jobs, thus strengthening insiders' power and raising structural unemployment. Empirical analysis suggested that, the more generous the eligibility requirements and the longer the duration of income support, the stronger the disincentives to work. In order to reduce these adverse effects, it would be key to reassess the eligibility, replacement rates, and 


\section{Box 7. Euro Area: The EU's Own Diagnosis and Recommendations on Labor Market Policles}

In November 1997, the European Council decided to initiate cooperation and monitoring in the area of labor market policies, thereby anticipating the ratification of the Amsterdam Treaty. At the center of this "Luxernbourg process" are Employment Guidelines, which provide the input on labor market policy for the EU's Broad Economic Policy Guidelines and are transiated by the member states into National Action Plans (NAPs) that are updated annually. The NAPs, in turn, provide a basis for monitoring the achievernents of the individual member states. This box presents the European Commission's main recommendations which the Council of Ministers, on the basis of the Commission's conclusions, has addressed to the member states for the reform of their labor markets.

The Guidelines ( 22 in all) are addressed to the EU merubership as a whole, without reference to issues at the country level. Based on a broad view of the labor market, they aim chiefly at fostering: (I) entry or re-entry into the active labor force, (2) business formation by removing administrative obstacles, (3) higher productivity through training at work and better organization of work, and (4) equal opportunities for women and disadvantaged groups. The Guidelines offer only a few quantified targets, related to a preventive approach to reduce the inflow into long-term unemployment by providing training and work practice to the jobless. Otherwise, it is left to the individual member states to tum the Guidelines into spocific measures as part of their NAPs.

Within the framepork of the Guidelines, policy recommendations are addressed to the individual member states. Although exonomic performance has varied considerably across the EU, all member states have been found in need of improving the functioning of the labor market. Taking the EU as a whole, the key findings are: (1) there is excessive unemployment among the young and those over 50 years of age; (2) expanding the services sector wovid create a large employment potential; and (3) inadequate and insufficient qualifications constitnte a serious obstacle to employment. A synopsis of the main recommendations addressed by the Council of Ministers to member states is presented in the table below.

\section{The Council of Minister's Recommendations}

\begin{tabular}{|c|c|c|c|c|c|c|c|c|c|c|c|c|c|c|c|}
\hline & Av & Be & De & $\mathbf{F}$ & $\mathbf{F r}$ & Ge & Gr & $\mid \mathbf{r} \mathbf{r}$ & |it & Lu & Ne & $|\mathbf{P o}|$ & $\mathrm{sp}_{\mathrm{p}}$ & $\mid s w$ & uk \\
\hline $\begin{array}{l}\text { Fight long term unejaployment through training } \\
\text { progrents if }\end{array}$ & & $\checkmark$ & & & & $\checkmark$ & $\checkmark$ & & $\checkmark$ & & $\checkmark$ & & $\checkmark$ & & \\
\hline Revien ters and benefit aystem & & $\checkmark$ & $\sqrt{ }$ & $\sqrt{6}$ & $\sqrt{7}$ & $\sqrt{71}$ & $\sqrt{ }$ & & $\checkmark$ & $\sqrt{7 t}$ & $\sqrt{71}$ & & & & \\
\hline Review carly retiresnent scheme & $\sqrt{ }$ & $\sqrt{7}$ & & $\checkmark$ & $\sqrt{7}$ & $\sqrt{ }$ & & & $\checkmark$ & & & & & & \\
\hline Reduce tares on Lohor & $\checkmark$ & & & $\sqrt{ }$ & $\checkmark$ & $\checkmark$ & & & $\sqrt{ }$ & & & & & $\checkmark$ & \\
\hline Improve tiducational aystem 2i & & & & & & & $\sqrt{7}$ & & & & & $\sqrt{ }$ & & & \\
\hline Inprove productivity at the enterprise level $3 /$ & & & & & & & $\sqrt{6}$ & $\checkmark$ & & & & 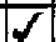 & & & $\checkmark$ \\
\hline Facilitate the creation of enterprises 4 & & $\sqrt{ }$ & & & $\checkmark$ & $\sqrt{ }$ & $\checkmark$ & $\checkmark$ & $\checkmark$ & & & $\sqrt{ }$ & $\sqrt{7}$ & & \\
\hline Foster equal opportunitles $s$ & $\boldsymbol{\gamma}$ & $\sqrt{\checkmark}$ & $\sqrt{6}$ & $\sqrt{ }$ & & $\sqrt{81}$ & $\checkmark$ & $\checkmark$ & $\sqrt{ }$ & $\checkmark$ & & & $\checkmark$ & 17 & $\sqrt{ }$ \\
\hline
\end{tabular}

Source: Council of the Eurapean Union, Council Recommendation on the Implementation of Member States Employment Policies, February 2000

/ Youth unemployment is a particularly serious probtem in Greece, Italy and the Netherlands

2/Improving and expanding lifelong learning has been reconmented, in one form of another, to all member states.

3/ By means of in-house vocational training and by fmproving the of ganization of work in cooperation with the social parthers,

$4 /$ By means of a strategy combining regulatory, fiscal, and labor market measures, and especially to exploit more fulty the potential of the servicess sector.

$5 /$ Exoep for Denmark; Finlend, Sweden and the Uniled Kingdom, all countries have a large gender employment gap.

$6 /$ By offering training and job opportunities to unemployed women.

7/ Especially to enoourage labor market participation of older workers.

8/ Reduce gender pay gap.

While the Guidelines have provided a helpful framework to address labor market rigidities in the euro area, this framework suffers from conceptual gaps. In particular, the Guidelines and the NAPs do not touch on the labor market's instiurtional framework (such as the arrangements for collestive wage bargaining) and eligibility conditions for prolonged unemployment insurance and welfare assistance. Issues related to insufficient wage differentiation, excessive and undifferentiated minimum wages, and regional problems within member states are equally not covered. Greater specificity and quantification of the recommendations to member states would set the stage for a better implementation at the country level. 
Table 9. Eura Area: 1.abor Market indecators

\begin{tabular}{|c|c|c|c|c|c|c|c|c|c|c|c|c|c|}
\hline & \multicolumn{3}{|c|}{ Howin Minimum Wase 17} & \multicolumn{2}{|c|}{ 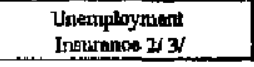 } & \multicolumn{2}{|c|}{$\begin{array}{l}\text { Unemployment } \\
\text { Asaistance af } 4\end{array}$} & \multicolumn{4}{|c|}{ 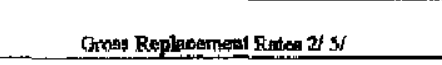 } & \multirow{2}{*}{ 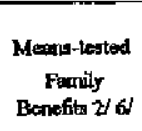 } & \multirow{2}{*}{$\begin{array}{l}\text { Enployniets } \\
\text { Coadilional } \\
\text { Bemefit } 2 / 1\end{array}$} \\
\hline & $\begin{array}{l}\text { Lowel B/ } \\
\text { (in US doilena) }\end{array}$ & $\begin{array}{l}\text { In percent of } \\
\text { inedian eneringen }\end{array}$ & 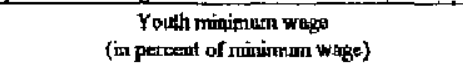 & Duration 9f & Paypent 10 & Duration $9 /$ & Payment soi & $\begin{array}{c}\text { Year } \\
1\end{array}$ & $\begin{array}{l}\text { Years } \\
2 \text { and } 3\end{array}$ & $\begin{array}{l}\text { Yean } \\
\text { A ands }\end{array}$ & $\begin{array}{l}\text { Overall } \\
\text { Averago }\end{array}$ & & \\
\hline Auntria & & & & 12 & 57 & na lirsit & 92 & 47 & 45 & ds & 31 & $\mathbf{N}$ & $\mathbf{N}$ \\
\hline Bolgium & 7.03 & 50.4 & $70 \% 6$ - $94 \%$ for worken betwoen 17 -20 yearx did & no tinit & 60 & n.e. & in. & 48 & 48 & d8 & 40 & $\mathrm{~N}$ & $\mathbf{N}$ \\
\hline Fankland & & & & 23 & 80 & no linnit & Hat rate & 54 & 39 & 27 & 36 & N & $\mathbf{N}$ \\
\hline France & 6.80 & 57.4 & $\mathrm{HO}$ & 60 & 73 & go linnit & fint vate & 58 & 37 & 94 & 76 & $\mathrm{~N}$ & $\mathbf{N}$ \\
\hline Ge्grntany & & & & 12 & 50 & ro linut & 5a & 34 & 32 & 32 & 26 & $\mathrm{~N}$ & $\mathbf{N}$ \\
\hline Iraland & 5.54 & 64.0 & $75 \%$ youlh rate planned & 15 & flal rive & תolinit & Alut rate & 48 & 49 & 49 & 30 & $\mathbf{N}$ & $\mathbf{r}$ \\
\hline Italy & & & & 12 & 80 & M.Q. & na. & 29 & v & a & $\mathbf{B}$ & $\mathbf{Y}$ & $\mathbf{N}$ \\
\hline Laxembourg & 6.73 & & 0096- $20 \%$ for wheres betwen $15-17$ years ofd & 12 & 80 & n.a. & n.a. & $\ldots$ & $\ldots$ & $\ldots$ &. & $\mathrm{N}$ & $\mathbf{N}$ \\
\hline Nethertands & 6.25 & 49.4 & 3996 - 85\% for warkent betwaen 15-22 youry efd & 60 & 70 & 24 & fint parte & 70 & 57 & 48 & 47 & $\mathrm{~N}$ & $\mathbf{N}$ \\
\hline Portagal & 1.89 & & $73 \%$ for thase under 18 yoars of age & 30 & 65 & 10 & Hent risto & 65 & 38 & a & $\mathbf{3 3}$ & $\mathrm{N}$ & $\mathrm{N}$ \\
\hline Spain & 2.56 & 32.4 & No & 24 & 10 & 6 & Ilat rate & 63 & 32 & 0 & 32 & $\mathrm{~N}$ & $\mathbf{N}$ \\
\hline ๘.K. & 5.82 & 46.0 & $89 \%$ for those under 21 years of age & 6 & flat rate & nor-limit & flai rente & 30 & 31 & 31 & 19 & $\mathrm{~N}$ & $\mathbf{Y}$ \\
\hline U.S. & 5.15 & 39.0 & No & 6 & so & ле. & m.a. & 20 & 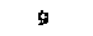 & 9 & 12 & $\mathbf{Y}$ & $Y$ \\
\hline
\end{tabular}

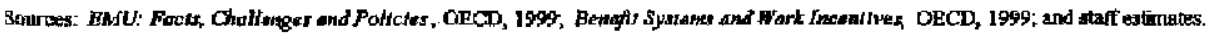

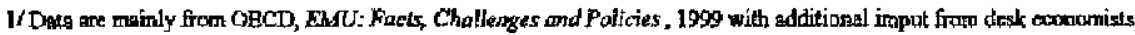

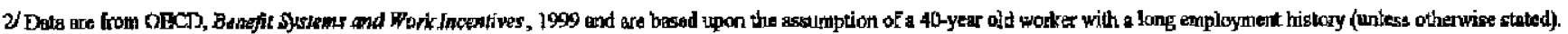

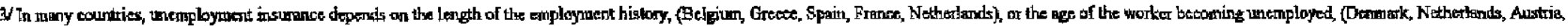
Portugal, Fintand, and Sineden). In aldition, aliding gales may be used to reduce the benefit anount as the length of unernployunent intrastes.

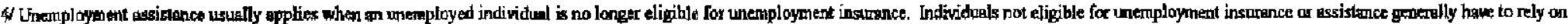

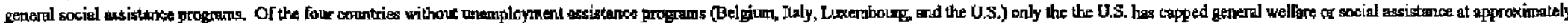

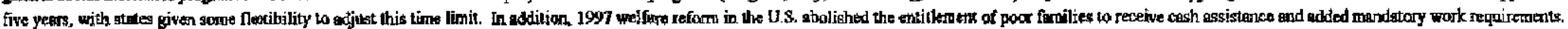

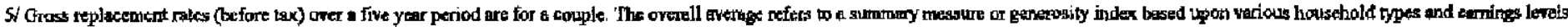

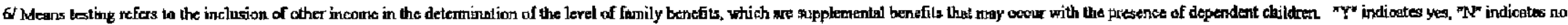

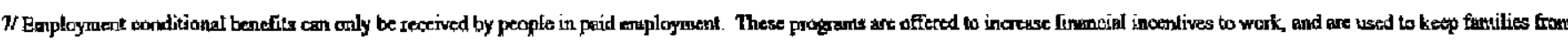

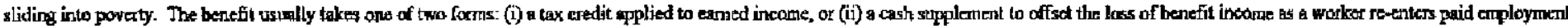

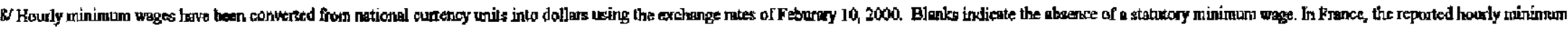

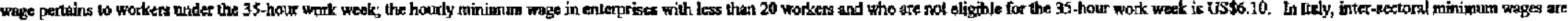
in place and a nationed standerd is not set.

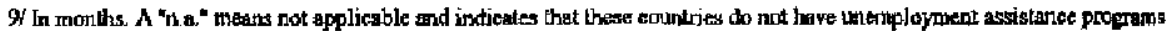

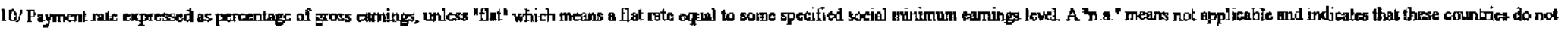
heve unemployment assistance programs. 
duration of benefits, and to have social assistance as a temporary and not a permanent entitlement in most cases. ${ }^{21}$

Joblessness in the euro area affected disproportionately the low-skilled and the inexperienced. There was a growing consensus that an important factor behind this trend had been the interaction of rigidities at the low end of the wage distribution with the effect of skill-biased technical progress, greater global trade, and the shrinking employment share of manufacturing and agriculture. The reliance on undifferentiated minimum wages in many countries, whether legal or contractual, had effectively priced low-productivity workers out of employment-a situation that could only be corrected by greater differentiation at the low end of the wage scale.

Active labor market programs - in particular training for the unskilled, the young, and the socially disadvantaged-had often proved effective in reducing unemployment. Their broad availability should be the counterpart of an equitable strategy aimed at encouraging job search and participation in the active labor force. Given the constraint imposed by the need to pursue fiscal consolidation in all euro-area countries, however, resources should be carefully channeled to the most cost-effective training and vocational programs and, when possible, their scope should be widened.

37. The mission took note of the fact that countries that had moved more decisively in these areas, such as Denmark, Ireland, the Netherlands, and the United Kingdom, were reaping the benefits of improved labor market performance. Hopeful steps had also been taken for example in Spain (where benefits had been selectively tightened) and Italy (where apprenticeship programs had been strengthened on a regional basis). In addition, ongoing tax overhauls (notably, in Italy and Germany) promised to increase the incentives to work. However, in the mission's opinion, insufficient wage differentiation (particularly in France, Germany, and Italy), and open-ended social assistance (in most countries) continued to hamper job creation and adversely affect structural unemployment in the euro area.

38. In response, officials at the Commission pointed out that much had been accomplished in labor and product market reform. They thought that insufficient credit had been given to these efforts in the mission's overall assessment of structural policies. Looking ahead, members of the Euro-11 ministerial group thought that more could be done to address endemic structural rigidities in the euro area, but argued that substantial social and economic payoffs could come from stepping up ongoing reform efforts without any pressing need to tackle more socially divisive issues. Finally, ECB representatives concurred with staff that structural impediments limited the euro-area growth potential and complicated the conduct of

\footnotetext{
${ }^{21}$ See World Economic Outlook, May 1999, Chapter IV, for a detailed analysis and references, at www.imf.org/external/pubs/ft/weo/1999/01/index.htm.
} 
monetary policy. In this connection, they expressed the hope that the national authorities would commit publicly and without delay to a more ambitious reform program.

\section{OTHER ISSUES}

39. The mission was briefed by representatives of the Commission who had just returned from the WTO Conference in Seattle. The EU position had centered on its advocacy of a comprehensive Round, including further liberalization or rule-making in the fields of agriculture and services, non-agricultural tariffs, investment, competition, trade facilitation, and environment. The EU had also proposed a detailed agenda to ensure that the needs and interests of developing countries were concretely reflected in the negotiations, including a substantial concession in the area of market access for poor countries. The officials ascribed the collapse of the talks to poor organization and intransigence manifested by major participants other than the EU, notably on issues such as anti-dumping and the implementation of Uruguay Round agreements. ${ }^{22}$ The EU had also found little support for its position on investment, competition, and environmental policies, which constituted important elements of a comprehensive agenda. In addition, the concerns of many industrial countries over issues of labor standards had also not been shared by the great majority of developing countries. EU representatives thought that, contrary to the common perception, agricultural issues had not been the main stumbling block in the talks - they felt that the EU had shown enough readiness to open negotiation on these matters. However, the lack of a successful outcome had been due for the most part to the absence of a spirit of compromise and of a willingness to make concessions in some areas to achieve progress in others. ${ }^{23}$

40. Concerning EU enlargement, Commission officials explained that the Kosovo crisis had catalyzed a deep change in the strategy. Considerations of political stability-and not only progress toward meeting the "Copenhagen economic criteria" and in the adoption of the acquis communautaire - had become important. In particular, the expectation of a fulfillment of the "Copenhagen economic criteria" in the medium term would no longer be a precondition for starting negotiation for EU membership, but these criteria would have to be met before accession. The mission took note of the increased emphasis on political factors and expressed hope that this would not undermine the push for economic reforms in prospective EU members.

\footnotetext{
${ }^{22}$ The staff's views on the Seattle Ministerial have been reported to the Board in The Seattle Ministerial and Prospects for a New Round (SM/31/00).

${ }^{23}$ The EU position on trade issues is described in Box 3 of SM/99/61, and may also be found at http://europa.eu.int/comm/trade/2000 round/position.htm
} 


\section{STAFF APPRatsal}

41. Economic conditions in the euro area have brightened in recent months and the nearterm outlook is quite favorable. The expansion has broadened, both geographically and across all components of aggregate demand, and price stability seems secure despite the surge in oil prices. The key policy challenge is now to create the conditions for a prolonged expansion.

42. Three policy requirements stand out as essential: a monetary strategy firmly focused on medium-term price stability but mindful of the need to cautiously probe the margins of untapped resources; national fiscal policies aimed at promoting favorable supply-side responses and creating room for maneuver; and stepped-up structural reform efforts, to fill in critical gaps undermining the overall effectiveness of the current reform strategy. To the extent that, in assessing area-wide developments, currency market participants tend to focus on the largest countries, it is precisely there that the need for deeper fiscal consolidation and tax reform, along with a comprehensive attack on structural rigidities, is particularly urgent.

43. The ECB is to be commended for a policy stance that-without taking any risks as to price stability - has been quite supportive of the economy throughout 1999 . This orientation should be maintained in 2000 . As the economic expansion strengthens in the course of the year, there will be a need for a gradual move toward a more neutral policy stance, but, even allowing for monetary policy lags, there would appear to be no pressing need for an increase in interest rates in the immediate future. In particular, the staff would note that: until recently, domestic final demand growth in the area as a whole has not been particularly buoyant (an increase of only 2.6 percent in 1999); the slack renaining in the goods and labor markets is expected to be absorbed only gradually; deregulation and privatization should continue to dampen utility prices; and wage moderation does not appear to be at risk. From this standpoint, the increase in the ECB's principal refinancing rate in eariy February 2000 may have come somewhat early.

44. The bulk of the euro-area economy, although undoubtedly weighed down by deepseated structural problems, suffers from unused productive potential, and monetary policy should cautiously explore the limits to non-inflationary growth, taking account of the widespread signs of an improved inflation-output trade-off elsewhere, and of the deflationary pressures coming from deregulation and other reforms within the euro area. In the few countries where the economy may already be operating above potential, the appropriate policy response is greater fiscal and structural adjustment and/or acceptance of the role of relative price changes, since monetary policy has to be set on the basis of conditions in the area as a whole. This said, there remain legitimate grounds for market participants' concerns that without further structural reforms, the potential for non-inflationary growth may be exhausted well before a reduction in unemployment to more acceptable levels is achieved.

45. Monetary management could be made more effective through even greater transparency in the ECB's communication strategy, which would enhance the predictability and the credibility of policy. While the ECB's decision to eschew an inflation-targeting 
approach is understandable-especially in the first years of monetary union when the relationships between money, prices, and interest rates are likely to be subject to an exceptional degree of uncertainty-the intention to publish macroeconomic projections, including projections of inflation, is welcome. This publication would help promote a better understanding of how monetary policy decisions are grounded on economic indicators, and of how the ECB forms its view on inflation risks. Prompt action along these lines could constitute a meaningful move toward reassuring financial markets.

46. The depreciation of the euro, which had helped jump-start the recovery, does represent a cause for concern now. In light of the strengthening of activity in the euro area and of the current and capital account imbalances among the major currency blocs, the currert weakness of the currency is undesirable. In particular, the lagged response of trade flows to a soft euro could exacerbate the current pattern of trade imbalances, even as the cyclical positions of the United States and the euro area converge, thus heightening the risks of abrupt exchange rate reversals and of protectionist pressures. Barring a disorderly depreciation, however, a monetary policy response would be appropriate only if adverse import price dynamics threatened medium-term price stability. To the extent that the depreciation reflects markets' worries about structural rigidities that undermine the sustainability of noninflationary growth, a monetary reaction in the absence of clear risks to price stability would-in all likelihood-do little to strengthen the currency.

47. While there has been remarkable progress toward fiscal sustainability in the run-up to EML, the fiscal adjustment effort has slackened somewhat in 1998-99, and now needs to be revamped. The new fiscal plans for 2000-03 make progress in this direction, but not enough. Compared with the older generation of Stability Programs, more sizable reductions in taxes are now envisaged in most countries-in part as a result of a helpful exercise of peer pressure within ECOFIN and the EFC. Nonetheless, for the euro area as a whole, the new plans do not provide the strong improvement in the structural primary balances and the bold reductions in the tax burdens that would have been desirable. Indeed, the targeting of budgetary deficits-.even smalt ones, four years from now-by the two largest euro-area members could hardly be reassuring to markets.

48. Manageable goals in the brightened cyclical setting would include achieving by 2003 a balance or surplus in all euro-area countries, while cutting the euro-area revenue burden by at least 2 percentage points of GDP from its 1998 level-bringing th to what it was before the tax hikes in the run-up to EMU. Attention must also be paid to the quality of the adjustment: even though steps are already underway in several countries to enhance the efficiency of the tax system, more remains to be done to ensure a durable reduction in public spending. This would require bolder reforms that may pay off only in the longer run. The needed reforms differ across the euro area, but streamlining the civil service, overhauling the healthcare systems, and further reforming pension schemes are priorities in most countries. 
49. As regards reforms in the labor and product markets, the need for ratcheting up the adjustment effort is even more obvious. Progress to date notwithstanding, the current strategy still suffers from both conceptual gaps and weak implementation. The authorities should accelerate the pace of the reforms envisaged in the agreed EU guidelines and openly recognize the need to tackle issues that so far have been considered as political taboos. In many countries, this should include a reassessment of the eligibility conditions for unemployment compensation and welfare assistance, with a view to restoring job search incentives. Moreover, people without proper training and work experience, or in economically depressed regions, should not be excluded from employment through an undifferentiated minimum wage rate or a rigid wage structure. Reforms in these areas should go hand in hand with greater efforts and resources to broaden the scope of the most effective vocational education and apprenticeship programs.

50. In the product and service markets, noteworthy progress continues to be made in privatization and deregulation - setting the stage for the beneficial impact of greater competition on price trends. However, there remains ample scope for promoting market access in still-sheltered sectors such as electricity-going well beyond the minimal thresholds of EU directives-as well as for reducing government involvement in commercial activities and liberalizing public procurement practices. High priority should also be given to removing administrative barriers to business formation and to the creation of empioyment in the service sector. In this context, the forthcoming country-specific reports by the Commission on progress on regulatory reform could go a long way toward stimulating adoption of best practices.

51. A harmonious and growth-friendly policy strategy should strengthen markets" confidence in the euro and foster a smooth resolution of current and capital account imbalances among the major currency blocs. As the euro appreciates over time, it would support the needed re-balancing in the components of aggregate demand, from external to domestic components in the euro area, and vice versa in the United States. The appreciation would also help dampen inflationary pressures in the euro area and lessen the need for interest rate action.

52. It is expected that the next consideration by the Executive Board of the monetary and exchange rate policies of the euro-area countries in the context of their Article IV obligations will take place prior to the 2000 Annual Meetings. Subsequently, consultations would follow the standard 12-month cycle. 
Euro Area Economic Indieatcrs

APPENDEXI [Annual percentage change)

\begin{tabular}{|c|c|c|c|c|c|c|c|c|c|c|}
\hline & 1091 & 1992 & 1993 & 1994 & 1995 & 1996 & 1997. & 1998 & 1999 & 20000 \\
\hline Real Dom $=$ tic Denound & 2.6 & 1.5 & -2.2 & 2.2 & 2.2 & 20 & 19 & 3.5 & 2.7 & 3.0 \\
\hline Public eonsiumption & 2.3 & 3.2 & 1,4 & 1.9 & 0.5 & 1.7 & 0.5 & 1.4 & 1.3 & 1.1 \\
\hline Private constuription & 3.2 & 1.9 & -0.8 & 1.5 & 1.9 & 1.4 & 1.6 & 3.0 & 2.5 & 2.9 \\
\hline Grotry fixed investatent & 1.7 & 0.2 & .6 .8 & 2.3 & 3.3 & 1.3 & 23 & 4.7 & 4.6 & 4.8 \\
\hline Final domestic demand & 2.7 & 1.8 & -1.6 & 1.6 & 1.9 & 1.4 & 1.6 & 3.0 & 2.7 & 3.0 \\
\hline Stackboilding $2 /$ & -0.1 & -0.3 & 40.6 & 0.6 & 0.3 & 0.5 & 0.3 & 0.5 & 0.0 & 0.0 \\
\hline Exterral balance 2 & -0.1 & 0.0 & 1,3 & 02 & 0.2 & 0.5 & 0.4 & -0.5 & -0.4 & 0.2 \\
\hline Exports of G\&B $y^{\prime}$ & 5.9 & 3.7 & 1.2 & 9.1 & 8.3 & 4.5 & 99 & 6.0 & 3.6 & 7.5 \\
\hline Injorts of GeE I & 6.6 & 3.2 & -5.2 & 8.7 & 7.9 & 2.5 & 89 & 8.7 & 5.4 & 7.3 \\
\hline Rese cDP & 25 & $\underline{1.5}$ & 0.8 & 24 & $\underline{23}$ & 1.4 & 23 & 2.8 & 22 & 3.1 \\
\hline \multicolumn{11}{|l|}{ Reswurce Utilingrition } \\
\hline Potential GDP & 2.9 & 2.4 & 2.2 & 2.1 & 2.0 & 2.1 & 2.2 & 23 & 2.4 & 1.4 \\
\hline Output Gap (Fa of potential) & 1.9 & 1.0 & -2.0 & +1.7 & -1.4 & -2.1 & .2 .1 & .1 .7 & -1.8 & .1 .1 \\
\hline Employment & 1.0 & -1.4 & -2.1 & -0.3 & 0.5 & 0.4 & 0.8 & 1.5 & 1.6 & 1.3 \\
\hline Unampl,rate ( $\%$ eflabor force) 4 & 8.3 & 9.2 & 10.9 & 11.7 & II. 4 & 11.6 & 11.6 & 109 & 9.9 & 9.3 \\
\hline \multicolumn{11}{|l|}{ Prtars agd Wages } \\
\hline GDP defietor & 4.8 & 4.3 & 3.5 & 27 & 2.9 & 2.3 & 1.7 & 1.7 & 1.3 & 1.5 \\
\hline Constimer proes st & 3.7 & 3.5 & 3.2 & 2.7 & 2.5 & 2.3 & 1.6 & 1.2 & 1,2 & 1,6 \\
\hline \multicolumn{11}{|l|}{ Maruffacturing } \\
\hline Houly labor costs & 7.7 & 7.2 & 5.5 & 3.1 & 3.6 & 4.0 & 28 & 1.8 & 3.1 & 3.3 \\
\hline Productivity & 4.0 & 3.3 & 2.3 & 80 & 4.0 & $2 . T$ & 5.2 & 3.0 & 2.1 & 2.3 \\
\hline 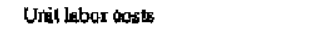 & 3.6 & 3.5 & 3.2 & .45 & -0.4 & 1.3 & .2 .2 & -1.1 & 1.0 & 1,0 \\
\hline \multicolumn{11}{|l|}{ Fint:th Indlogtors } \\
\hline \multicolumn{11}{|l|}{ Fiscal batance $6 /$} \\
\hline Central govennment & -4.0 & -4.2 & -5.1 & .4 .6 & -3.9 & -3.9 & -2.2 & -2.1 & .16 & -1.4 \\
\hline General governiment & -4.6 & $-4 . T$ & -3.7 & -5.2 & -5.2 & -4.3 & -2.4 & -2.1 & -1.2 & -0.9 \\
\hline Struntual balance & -5.7 & -5.2 & -4.4 & -4.1 & -4.2 & -29 & -1.0 & -1.1 & -0.4 & -0.4 \\
\hline \multicolumn{11}{|l|}{ interest rutes (in percent) } \\
\hline Shott-term & 10.6 & 11.1 & 8.6 & 63 & 6.5 & 4.6 & 4.1 & 39 & 3.0 & 3.9 \\
\hline Iong-terts & 19.1 & 9.8 & 8.1 & 8.2 & 8.5 & 7.1 & 3.9 & 4.7 & 4.6 & 5.7 \\
\hline Broad money fif & 8.0 & 7.9 & 6.8 & d.5 & 3.5 & 5.4 & 4.1 & 4.8 & 6,1 & $\ldots$ \\
\hline \multicolumn{11}{|l|}{ Real effectiva exchenge rate based on } \\
\hline nornealized ULC $(1999=1 \sqrt{50})$ & 96.9 & 100.0 & 97.8 & 95.8 & 100.3 & 100,4 & 89.3 & 85.8 & 80.7 & 76.3 \\
\hline \multicolumn{11}{|l|}{ Nornifial effective exchange rate } \\
\hline$(1990=100)$ & 97.4 & 100.7 & 97.0 & 95.3 & 99.5 & 99.7 & 90.9 & 99. & 86.7 & 82.7 \\
\hline \multicolumn{11}{|l|}{ Exterual Stater 7} \\
\hline Therent aecount balance & $-1,1$ & $\underline{-0,9}$ & 0.5 & 0.3 & 0.9 & 1.3 & 1.7 & 12 & $\underline{0.9}$ & 1.1 \\
\hline Trade balance & .0 .6 & -0.1 & 1.3 & 1.4 & 1.7 & 2.1 & 2.3 & 2.2 & 1.7 & 1.8 \\
\hline
\end{tabular}

Scaree: WEO fles.

1) WEO, Febriary 2000.

i) Contribution to grawth

3 Encludes intra-eurv awea trade.

4t Hesmonized deflinition

S/ Based on nationul inders until 1995 and hamondzed indices sabsequently.

6/ Percentage charge in the stock of M3, For 1999, the growth rate in the first eleven months. of 1999 . Fron the sume period in 1998.

$7 /$ In percent of GDP. 


\section{INTERNATIONAL MONETARY FUND}

EXTERNAL

Public Information Notice

RELATIONS

DEPARIMENT

Public tnformation Notice (PIN) No. 00/26

FOR IMMEDIATE RELEASE

April 3, 2000

International Monetary Fund

$70019^{\text {th }}$ Street, NW

Washington, D. C. 20431 USA

\section{IMF Executive Board Discusses the Monetary and Exchange Rate Policies of the Euro Area}

On March 15, 2000, the Executive Board concluded the discussion on the monetary and exchange rate policies of the euro area (in the context of the Article IV consultations with euroarea countries). ${ }^{1}$ The background section in this PIN reflects information available at the time of the Executive Board meeting and the views of Executive Directors are those expressed at that meeting

\section{Background}

Euro-area economic growth-which had slowed down in the wake of the emerging market crises - started to recover during the first half of 1999 on the strength of internal demand supported by a timely monetary easing, sustained employment creation, and improved business and household confidence. By mid-1999, the recovery in the global economy and a very competitive position of the euro catalyzed a further acceleration in aggregate real GDP growth, although the pattem of growth remained geographically imbalanced, with Germany and Italy lagging behind France and Spain, and the smaller peripheral economies leading the upswing. Labor market performance was also uneven across euro-area countries, but for the area as whole the unemployment rate continued to decline, reaching 9.6 percent by year-end.

' Under Atticle IV of the IMF's Articles of Agreement, the IMF holds bilateral discussions with members, usually every year. A staff team visits the country, collects economic and financial information, and discusses with officials the country's economic developments and policies. On return to headquarters, the staff prepares a report, which forms the basis for discussion by the Executive Board. At the conclusion of the discussion, the Managing Director, as Chairman of the Board, summarizes the views of Executive Directors, and this summary is transmitted to the country's authorities. The main features of the Board's discussion of the staff's report on the monetary and exchange rate policies of the euro area are described in this PIN. In the present case, the Fund staff held discussions with European Union institutions, including the European Central Bank (ECB), in the context of the Articie IV consuitations with the countries forming the euro area. The ECB's observer at the Fund participated in the meeting of the Executive Board. 
Throughout the year, headline inflation remained subdued, albeit increasing as a result of rising ail prices. It reached 2.0 percent (12-month basis) in January 2000, up from 1.7 percent last December. Core inflation-as measured by the aggregate Harmonized Index of Consumer Prices (HICP) net of its more volatile energy and food components-declined through October before edging up to about 1 percent at end-1999 and 1.2 percent in January 2000 .

In November 1999, the 50 basis points increase in the European Central Bank's (ECB) principal lending rate-which fully reversed the April easing - marked a shift to a more neutral monetary stance as risks to price stability turned to the upside. This shift was underscored by the further 25 basis point increase in February 2000. Monetary conditions, though, remained supportive of activity throughout, in part as a result of the weakness of the euro, which depreciated on a multilateral basis by about 12 percent both in nominal and (unit labor cost-based) real effective terms in the course of 1999 and by an additional 2.0 percentage points through early March 2000 .

As regards fiscal developments, 1999 budgetary targets were met by virtually all countries in the euro area, often despite slower-than-anticipated GDP growth. Yet, after the remarkable progress in the run-up to Stage 3 of the Economic and Monetary Union, the area-wide deficit reduction (from a deficit of 2.0 percent of aggregate GDP in 1998 to a deficit of 1.2 percent of GDP in 1999) was modest and largely accounted for by lower interest payments. The 2000 budget targets envisage an area-wide deficit-to-GDP ratio of about 1 percent.

On current WEO projections, aggregate real GDP growth would exceed 3.0 percent in 2000. Inflation is expected to remain benign, with headline HICP inflation tapering off by end-2000 to about 1.5 percent and remaining well within the ECB's definition of price stability, against the backdrop of the remaining slack in the euro-area economy. Regional divergences in growth and inflation rates, reflecting in part the catching-up process in many EMU countries, are expected to continue, although narrowing somewhat.

Risks to the near-term outlook appear balanced for inflation and, if anything, on the upside for economic activity. On the downside, real growth projections are mainly subject to uncertainties stemming from the global environment-most importantly, the timing and intensity of a possible slowdown in the United States.

\section{Executive Board Assessment}

Noting that the near-term outlook for the euro area had brightened with the deepening and broadening of the recovery, Executive Directors stressed that the key policy challenge now is to create conditions for a long period of rapid economic growth.

To this end, Directors urged the pursuit of a monetary strategy firmly focused on price stability, the implementation of national fiscal policies aimed at promoting public saving and favorable supply-side responses, and the intensification of structural reform efforts. 
Directors commended the ECB for a policy stance that had been quite supportive of the economy throughout 1999, without endangering medium-term price stability. While acknowledging the need for a gradual return to a more neutral position as the cycle matured, many Directors thought that this supportive orientation should be maintained in 2000 . In particular, they saw no pressing need for an increase in interest rates in the near future, in light of the remaining slack in labor and product markets, the gradual pace at which it has been taken up, the prevailing moderation in wage claims, and the downward pressures on prices stemming from deregulation in key sectors. These Directors also argued that monetary policy should be mindful of the need to probe cautiously the margins of untapped resources, taking into account some signs of an improved inflation-output trade-off in the euro area, as had occurred in the United States. Some Directors, however, considered that risks to price stability are on the upside-owing inter atia to generous liquidity conditions in 1999 and still rising oil and commodity prices-and that it remains necessary to react quickly to threats of inflation. A few of these Directors observed in this connection that further careful analysis is needed to assess whether the euro area had, in fact, seen an improvement in the inflation-output trade-off. More generally, Directors agreed that the steadfast pursuit of structural reforms offers the best chance for non-inflationary growth in the euro area and the maintenance of market confidence, while allowing monetary policy to focus on continued price stability.

Directors observed that the ECB had made important strides in providing information to the public on its strategy and its assessment of economic conditions, but indicated that greater transparency could make monetary management more effective. In this connection, they welcomed the intention to publish macroeconomic projections, including projections of inflation - which, without implying a departure from the accepted monetary policy strategywould promote a better understanding of how the ECB forms its views of the inflation outlook, and would enhance the credibility and predictability of policy.

Against the backdrop of stronger activity in the euro area and of the current and capital account imbalances among the major currency zones, Directors agreed that the current weakness of the euro is undesirable. They underscored that lagged exchange rate responses of trade flows could exacerbate existing patterns of trade imbalances and heighten the risks of abrupt exchange rate reversals and of protectionist pressures.

Directors remarked, nonetheless, that a monetary policy reaction would be appropriate only if there were a threat to medium-term price stability. They noted that, to the extent that a weak euro reflected the relative cyclical positions of the United States and the euro area, as well as markets ${ }^{1}$ concerns about the structural rigidities that could undermine the sustainability of the expansion, a monetary response in the absence of clear risks to price stability would do little to strengthen the currency. In their view, a recovery of the euro would come from markets becoming better attuned to the fundamental strength of the euro-area econamy, greater cyclical convergence between the United States and the euro area, and greater progress on structural and fiscal reform in many euro-area countries.

Directors acknowledged the progress toward fiscal sustainability in the run-up to Stage 3 of the Economic and Monetary Union. Most Directors pointed out, however, that the adjustment effort 
had slackened in 1998-99 and needed to be reinvigorated. Such improvements are necessary to create the room for discretionary fiscal policy that is particularly important in the framework of a uniform monetary policy. These Directors indicated that, although the updated stability programs for 2002-03 were, in some cases, more ambitious than the previous ones in proposing tax cuts, the programs did not go far enough to provide the area as a whole with the necessary improvements in structural primary balances and reductions in tax burdens.

Directors argued that in the improved cyclical setting, manageable targets for 2003 should include the achievement of fiscal balances or surpluses in all eurc-area countries, and reductions in the euro-area revenue-to-GDP ratio. Directors also stressed the importance of ensuring durable improvements in the fiscal positions of most countries by further reforming health care and pension systems-measures that would guarantee lasting reductions in public spending. Such spending restraint is essential to allow tax rates to be reduced significantly from current levels, while maintaining fiscal prudence and achieving the approximate fiscal balances or surpluses envisaged under the Stability and Growth Pact.

Turning to the labor and product markets, Directors observed that considerable progress had been made in reforming the product, services, and capital markets. Directors noted, however, that the euro-area reform strategy is still too limited in scope. In order to continue cutting areawide unemployment, they urged the authorities to accelerate the pace of labor market reform.

In the labor market most Directors saw the need in many countries to reassess the eligibility conditions for unemployment compensation and welfare assistance, promote a less rigid and more differentiated wage structure, and broaden the scope of the most effective vocational and apprenticeship programs.

In the product and service markets, Directors welcomed the ongoing progress in privatization and deregulation, but called for stepped-up efforts to lock in the beneficial effects of competition. They noted the ample scope for further opening up access to still sheltered sectors, as well as for removing administrative barriers to business formation, and to job creation in the service sectors and commercial activities.

Some Directors noted that trade liberalization offers important benefits not only for augmenting world growth potential, but also for the euro countries themselves, in terms of the implications for domestic prices, resource allocation, and the external position. They encouraged the euro countries to allow increased market access to exports from low-and middle-income countries, noting that trade protection, especially in agriculture, remains high.

Public Information Notices (PINs) are issued, (i) at the request of a member country, following the conclusion of the Article IV consultation for countries seeking to make known the views of the IMF to the public. This action is intended to strengthen IMF surveillance over the economic policies of member countries by increasing the transparency of the IMF's assessment of these policies; and (ii) following policy discussions in the Executive Board at the decision of the Board. 


\section{Euro Area: Selected Economic Indicators}

\begin{tabular}{|c|c|c|c|c|c|c|}
\hline & 1995 & 1996 & 1997 & 1998 & 1999 & $2000^{\top}$ \\
\hline Real Economy & \multicolumn{6}{|c|}{ In percent } \\
\hline Change in real GDP & 2.3 & 1.5 & 2.4 & 2.8 & 2.3 & 3.2 \\
\hline Change in final domestic demand & 1.8 & 1.5 & 1.7 & 3.1 & 2.8 & 3.0 \\
\hline Change in consumer prices 2,3 & 2.9 & 2.3 & 1.6 & 1.2 & 1.2 & 1.7 \\
\hline Unemployment rate $e^{2,4}$ & 11.3 & 11.6 & 11.6 & 10.9 & 10.1 & 9.4 \\
\hline Public Finance & \multicolumn{6}{|c|}{ In percent of GDP } \\
\hline General government balance & -5.1 & -4.4 & -2.6 & -2.0 & -1.2 & -0.9 \\
\hline Public debt & 70.4 & 74.4 & 74.0 & 73.4 & 72.2 & 71.1 \\
\hline Money and Interest Rates & \multicolumn{6}{|c|}{ In percent } \\
\hline Change in $M 3$ (end of year) ${ }^{2}$ & 5.7 & 4.0 & 4.1 & 4.5 & 6.4 & $\ldots$ \\
\hline Money market rate ( 3 month money) & 6.1 & 4.6 & 4.1 & 3.9 & 3.0 & $3.8^{5}$ \\
\hline Government bond yield ( 10 year bonds) & 8.5 & 7.1 & 5.9 & 4.7 & 4.6 & $5.3^{5}$ \\
\hline Balance of Payments & \multicolumn{6}{|c|}{ In percent of GDP } \\
\hline Trade balance & 1.8 & 2.2 & 2.5 & 2.4 & 1.8 & 1.9 \\
\hline Current account & 0.8 & 1.3 & 1.8 & 1.3 & 0.7 & 1.1 \\
\hline \multirow[t]{2}{*}{ Official reserves (US\$ billion) } & & & & & & $254.0^{6}$ \\
\hline & \multicolumn{6}{|c|}{ In percent } \\
\hline Exchange Rates & & & & & & \\
\hline Nominal effective rate & 4.5 & 0.1 & -8.8 & -0.1 & -4.5 & $-7.6^{7}$ \\
\hline Real effective rate & 4.7 & 0.1 & -11.0 & -3.9 & -5.7 & $-9.6^{7}$ \\
\hline
\end{tabular}

Sources: European Central Bank; EUROSTAT; national authorities; and IMF staff estimates.

1 Staff projections.

2 Harmonized definition.

${ }^{3}$ For 1995 based on national definitions.

${ }^{4}$ In percent of labor force.

5 March 15, 2000.

* Total reserves minus gold (Eurosystem definition); end January.

7 March 15, 2000 relative to 1999 average. 


\section{Statement by João Santos on Monetary and Exchange Rate Policies of the Euro Area March 15, 2000}

As you may know, Portugal presently holds the Presidency of the European Council. My statement expresses the common views of the Euro-area Member States and of the European Community/EMU in their respective fields of competence.

1. We welcome the well-balanced assessment of economic developments and prospects in the euro area that has been prepared by the staff. We are in broad agreement with the conclusions of the assessment but would make the following comments.

\section{Sustainability of economic recovery}

2. The short-term forecasts for growth in the euro-area economy correspond closely to those of our national authorities and of the European Commission. Growth rates of around 3 percent per annum are now projected for 2000 and 2001, as are a more balanced composition between domestic and external sources and a contimued increase in employment. The policy challenge, as indicated in the staff assessment, is to sustain this improved economic performance into the medium term by maintaining a clear commitment to macroeconomic stability and appropriate structural reform. In this context, it has to be highlighted that important structural changes have been introduced in the euro-area economy and will continue to be carried out, although at a different pace among Member States. Euro-area policymakers have increasingly seen structural reform as complementary to macroeconomic stability and a key factor to sustainable growth.

\section{Monetary Policy and Price Stability}

3. The ECB welcomes the staff's broad support for its monetary policy strategy, especially its agreement that the strategy should be "firmly focused on medium-term price stability." The ECB also welcomes the staff's view that monetary policy responses to exchange rate developments "would be appropriate only if [these exchange rate developments] threatened medium-term price stability." This is in line with the Eurosystem's strategy, which treats the exchange rate as one of the indicators of risks to price stability (in the context of the "second pillar" of the strategy).

4. However, in the view of the ECB, the report undervalues the information content of money as an indicator of future price developments in the euro area. There is a wide range of available evidence on the empirical properties of money in the euro area which justifies that the ECB assigns money a prominent role in its strategy. 
5. Turning to actual policy decisions, the ECB agrees with the staff's view that, with a continued strengthening of real activity in the course of 2000 , short-term nominal interest rates will have to rise in the future so as to maintain price stability over the medium term. Having said this, the ECB does not fully share the staff's view that monetary policy should "cautiously explore the limits to non-inflationary growth. "Since such an approach presumes an exploration of only the upper limits, it is inherently asymmetric and therefore likely to result in an inflationary bias. On the contrary, the ECB supports the view that structural reforms introduced in a context of price stability offer the best chance of increasing noninflationary growth in the euro area.

6. In this light, the ECB would not agree that the February 2000 interest rate increase "may have come somewhat early." In this connection, it should be recognized that, as early as the December 1999 ECB Monthly Bulletin, potential upside risks to price stability stemming from possible adverse developments in monetary and credit aggregates, oil prices and the euro exchange rate in the future had already been identified.

7. As the ECB subsequently made clear, oil and commodity price rises and the continued depreciation of the euro in December 1999 and January 2000 were both greater and more protracted than previously anticipated. Moreover, even though the monetary dynamics were more subdued in the second half of 1999 than earlier in the year, sustained strong M3 growth since January 1999 had resulted in a sizeable monetary overhang which, in conjunction with continued strong credit growth, signaled generous liquidity conditions in the euro area at the end of 1999 . Taken together with the significant improvement in the growth prospects for the euro area (also reflected in the staff's own forecast), the Governing Council concluded on February 3, 2000 that a further increase in interest rates should not be delayed, since otherwise upside risks to price stability would become manifest and the credibility of the single monetary policy might be placed at risk.

8. At its meeting on March 2, 2000 the Governing Council stressed that, taking into account the entire economic and financial picture and in view of the improving economic conditions, upside risks to price stability in the medium term continue to derive from a number of factors. These include monetary developments and the potentially lasting repercussions of rising oil prices and the effects from the past depreciation of the exchange rate on consumer price inflation. In this context, developments in the exchange rate remain a cause for concern. Nevertheless, given the euro's firm foundation on internal price stability, the ECB shares the view that in the medium term the euro has strong upward potential.

9. Looking forward, the ECB notes that the WEO forecast of February 2000 assumes an average euro-area short-term nominal interest rate over 2000 of 3.9 percent. This would imply a significant rise in interest rates in the remainder of 2000 over their current levels, which in turn would explain in part why the staff's reported forecast outlook for price stability is so favorable. In view of this assumption, the ECB finds unconvincing the conclusion drawn by the staff, namely that "there would appear to be no pressing need for an increase in interest rates in the immediate future." 
10. Overall, the ECB believes the staff's assessment that "price stability seems secure despite the surge in oil prices" is too complacent. Relative to the staff's forecast, the ECB's own assessment points to the potential for more persistent upside risks to price stability, largely associated with imported cost pressures, the expected strength of economic activity, and the lagged effects of generous liquidity conditions following strong M3 and credit growth during 1999. In the absence of an appropriate policy response to these threats, the outlook for continued price stability would be jeopardized.

\section{Exchange rate developments}

11. Developments in the exchange rate of the euro do not reflect the underlying strength of the euro-area economy. It is therefore the view of the euro-area authorities that in the medium term the euro has strong upward potential. With respect to shorter-term developments in the euro exchange rate, we view the depreciation since January 1999 as reflecting for the most part not so much the "market confidence" as the unexpectedly robust performance of the US economy relative to that of the euro area. Although the timing of any change in the exchange rate trend is difficult to predict, the prospect of diminishing growth differentials between the United States and the euro area suggests that there is room for an appreciation of the euro exchange rate. As regards an orderly resolution of global imbalances, it might help if the euro gains strength. However, the low domestic saving ratio in the US is the most crucial factor here. Europe itself has a sustainable current account balance. A slight surplus is normal for industrialized countries, as capital exports are required to finance the development of emerging markets. Moreover, the aging of the population in Europe requires savings.

\section{Fiscal policies in a medium-term perspective}

12. We acknowledge the need for a continuation of fiscal discipline, structural reform and wage moderation at the national level in order to maintain price stability in the medium term. In particular, it is important to prevent second round effects from the rise in oil prices on wages and prices. Regarding fiscal policies in the euro area, we are in broad agreement with the staft's assessment. It wishes to emphasize the continued commitment of the Member States to sound public finances and fiscal discipline, which was confirmed despite the slowdown in the euro-area economy in the first half of 1999. As a result, the budget deficit in the euro area declined to about 1.6 percent in 1999, after 2 percent in 1998. As the budget figures for 1999 are now finalized, the outcomes for 1999 could even be better. Moreover, the outcomes expected in 2000 and 2001 will be in most countries in line with the requirements of the Stability and Growth Pact.

As to the concern of the staff that the consolidation process may come to a halt, it should be pointed out that it is not justified, for at least three reasons:

(a)- the level of primary surpluses is high; 
(b)- economic assumptions are generally conservative;

(c)- the perceived lack of ambition must be assessed in the light of the more general goal of improving the quality and sustainability of public finances. Structural reforms and tax reductions may, in the short term, imply a slower speed in the fiscal consolidation process. Overall, the respect of the targets set in the stability programs will deliver a sound medium term position.

13. The staff assessment mentions some shortcomings in the medium-term orientations of fiscal policy concerning the room for maneuver for the automatic stabilizers, the budgetary implications of aging, the tax burden, and uneven progress in public spending reductions. The EU is aware of the need to address increasingly these issues by a combination of fiscal prudence and an overall trend toward reducing the weight of the public sector in the economy, based on quality and sustainability considerations. Any easing of the tax burden should neither jeopardize the "close-to-balance" or surplus requirement of the Stability and Growth Pact nor increase the inflationary pressures. It should take into account the need to rapidly reduce high public debt ratios and, at the same time, catalyze favorable supply-side responses. Therefore, a steady reduction in tax rates should go hand in hand with restraint in public spending, an increase in the efficiency of the taxation systems, and a broadening of the tax base. In this context, we agree on the need to accomplish structural reforms on the expenditure side, among others, and where needed through improvement of the efficiency of public institutions.

\section{Progress in strwctural reform}

14. We recognize the crucial importance of appropriate structural policies in improving the conditions for sustainable high rates of economic growth and employment creation and generally subscribe to the staff's recommendations. While acknowledging that more needs to be done in reforming the markets for products, services, capital, and labor, we feel that progress already achieved has not been properly reflected in the staff assessment. In particular, we would point to major achievements in privatization, deregulation and liberalization. Despite ongoing increases of employment throughout the euro-area, the structural framework conditions in the labor markets needed for higher sustainable employment in Europe have to be improved, in particular the modernization of social security systems. The process of structural reform bas moved to the top of the EU policy agenda and will be given further momentum at the forthcoming special meeting of EU Heads of State or Government in Lisbon, which will focus on how to enhance the efficiency and dynamism of the European economy while maintaining a strong commitment to the principles of social justice. The EU expects a commitment to accelerate the implementation of the necessary structural reforms. Moreover, three priorities may be highlighted: deeper integration of EU financial markets, development of risk capital, improvement of the quality and sustainability of public finances.

15. The staff assessment suggests that the reform strategy suffers from implementation and conceptual gaps. However, the EU considers that the existing policy framework is broadly 
adequate to promote a smoothly functioning economic and monetary union. Procedures are in place that cover the entire field of economic policies. Emphasis is now given to effectively applying arrangements and to closely monitoring policy implementation. To this effect, we agree in particular on the need to fully use the procedures relating to the Broad Economic Policy Guidelines (BEPG). Accordingly, the BEPG exercise for 2000 will be preceded by a discussion of implementation of the 1999 guidelines by the Council of Economic and Finance Ministers on the basis of a report prepared by the European Commission. Efforts to increase the specificity of the guidelines and to make, if necessary, specific recommendations to certain Member States will proceed. In this context, it is essential to maintain an appropriate balance between peer pressure at the level of the Union and the need for flexibility of policy measures at the level of the Member States, taking into account differences in economic structure and developments. 